\title{
Akademik Başarının Okul, Aile ve Öğrenci Özellikleri ile İlişskisinin Çok Düzeyli Yapısal Eşitlik Modellemesi ile İncelenmesi ${ }^{1}$
}

\begin{tabular}{lccc}
\hline MAKALE TÜRÜ & Başvuru Tarihi & Kabul Tarihi & Yayın Tarihi \\
Araştırma Makalesi & 11.02 .2019 & 21.06 .2019 & 04.10 .2019 \\
\hline
\end{tabular}

\author{
Gülçin Uzun (iD) 2 \\ Bilnet Okulları
}

\author{
Ömay Çokluk Bökeoğlu (D) 3 \\ Ankara Üniversitesi
}

Öz

Bu çalışma ortaokul 6, 7 ve 8. sınıfa devam eden öğrencilerin akademik başarıları ile okul, aile ve öğrenci özellikleri arasındaki ilişkinin çok düzeyli yapısal eşitlik modellemesi ile incelenmesi amacıyla yapılmıştır. 2016-2017 öğretim yılının birinci döneminde Ankara ili Çankaya, Keçiören, Mamak, Altındağ ve Yenimahalle ilçelerinin her birinden seçilen beş resmi ve iki özel okul olmak üzere toplam 35 okulda öğrenim gören 6,7 ve 8 . sinıf öğrencileri örneklemi oluşturmaktadır. Araştırmada verilerin toplanması amacıyla araştırmacı tarafından geliştirilen öğrenci bilgi anketi, Alkan (2015) tarafından geliştirilen Akademik Ortamlarda Olumsuz Değerlendirilme Korkusu Ölçeği ve Türkçe'ye uyarlaması Korkmaz (2002) tarafından yapılan Akademik Risk Alma Ölçeği kullanılmıştır. Araştırma sonucunda grupiçi düzeyde sosyoekonomik düzey, olumsuz değerlendirilme korkusu ve akademik risk alma davranışı değişkenlerinin akademik başarıya olan doğrudan etkilerinin manidar olduğu belirlenmiştir. Sosyoekonomik düzey ve akademik risk alma davranışı değişkenlerinin akademik başarı üzerinde pozitif yönde etkisi varken, olumsuz değerlendirilme korkusunun akademik başarı üzerindeki etkisi negatif yöndedir. Sosyoekonomik düzey değişkeni akademik bașarıyı doğrudan etkilediği gibi, olumsuz değerlendirilme korkusu ve akademik risk alma davranışı aracılığıyla da etkilemektedir. Gruplararası düzeyde sınıf öğrenci sayısı ve öğretmen başına düşen öğrenci sayısı değişkenlerinin akademik başarıya olan doğrudan etkileri manidardır.

Anahtar sözcükler: Akademik başarı, çok düzeyli yapısal eşitlik modellemesi, olumsuz değerlendirilme korkusu, akademik risk alma davranışı, aracılık.

${ }^{1} \mathrm{Bu}$ çalışma, birinci yazarın Prof. Dr. Ömay Çokluk Bökeoğlu danışmanlığında tamamlanan doktora tezinden türetilmiştir.

${ }^{2}$ Sorumlu Yazar: Dr., Bilnet Okulları, E-posta: cirakgulcin@ gmail.com, https://orcid.org/0000-0003-48976507

${ }^{3}$ Prof. Dr., Eğitim Bilimleri Fakültesi, Eğitim Bilimleri Bölümü, Eğitimde Ölçme ve Değerlendirme Anabilim Dal1, E-posta: cokluk@education.ankara.edu.tr, https://orcid.org/0000-0002-3879-9204 
Ülkeler eğitim aracılığı ile nitelikli öğrenciler yetiştirmeyi hedefler. Bu hedefe ulaşmak için öğrencilerin becerilerinin geliştirilmesi ve gelişime etki eden etmenlerin belirlenmesi gereklidir; çünkü öğrencilerin akademik başarıları, eğitim sisteminin etkililiğinin bir göstergesi olarak kabul edilir. Öğrencilerin akademik başarılarının nasıl yükseltileceğini belirlemek, başarısızlığa yol açan değişkenleri aramak, bunların nasıl ortadan kaldırılabileceğini belirlemek ve eğitim sistemini iyileştirmek, hemen her dönemde eğitim alanında gerçekleştirilen çalışmaların en temel amacı olmuştur.

Türkiye gibi gelişmekte olan ülkelerde sosyo-ekonomik düzey ve eğitim düzeyi gibi etmenlere bağlı olarak şekillenen aile altyapısının akademik başarı üzerindeki etkisi, her geçen gün daha fazla dikkat çeker ve yadsınamaz duruma gelmektedir (Dünya Bankas1, 2013; Oral ve McGivney, 2013; Organisation for Economic Cooperation and Development-OECD, 2012). Uluslararası Öğrenci Değerlendirme Programı'nda (Programme for International Student Assessment-PISA) daha düşük performans göstererek alt siralarda yer alan ülkelerde, öğrencinin sahip olduğu sosyoekonomik düzey ile akademik başarısı yakından ilişkili bulunmaktadır (OECD, 2012a). Sahip olunan meslek, gelir ve eğitim düzeyi gibi faktörler sosyoekonomik düzeyi ortaya çıkarmakta ve bu düzey bireyin toplum içerisinde konumunu, değerlerini ve dolayısıyla karar değişkenlerini etkileyen bir olgudur. PISA-2012 uygulamasında Türkiye'deki öğrencilerin tüm alanlara ilişkin başarı farklılıklarının \% 9'u, OECD'de ise \% 13'ü sosyoekonomik durumdaki farklılıkla açıklanmaktadır. Oysa eğitimde firsat eşitliğinden söz edebilmek için bu oranın çok daha düşük olması gerekmektedir (Oral ve Mcgivney, 2013).

Türkiye'de ve yurt dışında yapılan araştırmalarda daha üst sosyoekonomik düzeye sahip (Anıl, 2009; Berberoğlu, Çelebi, Özdemir, Uysal ve Yayan, 2003; Chiu, 2007; Hazır-Bıkmaz, 2001; Karabay, 2012; Lemke ve diğ., 2002; Polat, 2008; Sun ve Bradley, 2011) annebabalarının eğitim düzeyi daha yüksek (Anıl, 2009; Boztunç, 2010; Hazır-Bıkmaz, 2001; Karabay, 2012; Lemke ve diğ., 2002; Özer, 2009) öğrencilerin başarılı olma olasılıklarının daha yüksek olduğu belirlenmiştir. Öğrencilerin akademik başarıları ile ilişkili çalışmalar yalnızca ailenin sosyo-kültürel özellikleri, okul, sınıf ve öğretmen özellikleri gibi değişkenlerle sınırlı değildir. Alanyazında daha az incelenmiş olmakla birlikte, öğrencilerin duyuşsal özelliklerinin akademik başarılarını etkilendiğine yönelik bulgular da mevcuttur. Öğrenme etkinliğinde aktif rol alma çabasını duyuşsal özellikler etkilemektedir (Erden ve Akman, 2011; Özkan, 2005; Tok, 2008).

Bloom tarafından geliștirilen okulda öğrenme modeli olarak da adlandırılan tam öğrenme modelinde yer alan akademik tutum, akademik benlik, ilgi özellikler duyuşsal giriş özellikleri olarak tanımlanır ve bu özellikler öğrenci başarısında görülen farklılıkların \% 25'ini açıklama gücündedir (Senemoğlu, 2009). Alanyazın incelendiğinde, öğrenci başarısındaki değişkenliği açıklama gücü ya da ilişkisi bulunan duyuşsal özelliklerin başında tutum, anksiyete, ilgi, özbenlik, güdülenme vb. saptanmıştır (Akbaba, 2006; Gömleksiz ve Yüksel, 2003; Hemmings, Grootenboer ve Kay, 2011; Hortwitz, 2001; Karasakaloğlu ve Saracaloğlu, 2009; Wigfield ve 
Wentzel, 2007). Ancak, duyuşsal özelliklerin akademik başarı değişkenliği üzerinde sahip olduğu bu etki (Ellez, Gümüş ve Seferov, 2009; Gömleksiz, 2003) akademik ortamlarda olumsuz değerlendirilme korkusu ve akademik risk alma davranışları (Alkan, 2015; Çetin, İlhan ve Yılmaz, 2014; Çiftçi, 2006) gibi farklı duyuşsal özelliklerin de dikkate alınması gerektiğine işaret eden önemli bir göstergedir. Böylece başarıdaki değişkenliğin (varyansın) daha büyük bir kısmının açıklanması da söz konusu olabilecektir.

Akademik ortamlarda olumsuz değerlendirilme korkusu ise öğrencilerin okulda öğretmenleri ve arkadaşları, evde ise ebeveynleri tarafından akademik başarılarının olumsuz değerlendirilmesinden korkması anlamına gelmektedir. Olumsuz değerlendirilme korkusu yaşayan öğrenciler sınıf içerisinde yapılan tartışmalara katılma konusunda isteksiz olmakta, yanlış olabilir korkusuyla fikirlerini söylememekte ve arkadaşlarının gözünde küçük düşme kaygısıyla soru sormamaktadır (Alkan, 2015). Alanyazında olumsuz değerlendirilme korkusu ve akademik başarı arasındaki ilişkiyi inceleyen çalışmalar (Abuelfadl, 2015; Alkan, 2015; Karabulut ve Bahadır, 2013; Yokuş, 2013) olumsuz değerlendirilme korkusu ve öğrenci başarısı negatif yönde manidar bir ilişki olduğu sonucuna ulaşmışlardır.

Öğrencilerin olumsuz değerlendirilme korkuları ile birlikte akademik başarı ile ilişkilendirilebilecek bir başka duyuşsal özellik ise akademik risk alma davranışıdır. Bir öğrenme ortamında sonuçları ön görülemeyen veya üretilecek sonuçların olumsuz olabileceği düşünülen tehditlere karşın düşüncelerini dile getirme ve savunma becerisi akademik risk alma davranışı olarak tanımlanmaktadır (Denrell, 2007; Feldman, 2003). Akademik risk alma davranışı gösteren öğrenciler ileri sürdüğü fikirlerin ve çözüm önerilerinin olumsuz sonuçlanma olasıllğ̆ olsa bile, öğrenme ortamında tahminlerde bulunurlar. $\mathrm{Bu}$ durum öğrencilerin öğrenme ortamında karşılaşılan güçlüklerle mücadele etmedeki cesaretlerini yansitır.

Olumsuz değerlendirilme korkusuna sahip kişiler olumsuz sonuçlara katlanamadıkları için herhangi bir eylemi yerine getirme riskini de almamaktadırlar (Halstead ve Taylor, 1996). Alanyazında akademik risk alma ile olumsuz değerlendirilme korkusu arasında manidar ilişki olduğunu ortaya koyan çalışmalar bulunmaktadır (Boyer, 2006; Boztaş ve Sungur, 2001; Clifford, 1991; Çetin ve diğ., 2014; Durmuş, 2008; House, 2002).

Öğrencilerin başarısında, sosyoekonomik düzey, psikolojik özelliler gibi kişisel birtakım değişkenler kadar önemli olan bir başka etken, öğrenim gördükleri okulun özellikleridir (Acar, 2013; Akkalkan, 2009; Yıldırım, 2012). Öğrenci sayısının kalabalık ya da az olması eğitimin niteliğini doğrudan etkilemektedir. Okulların yeterli sayıda olmaması sınıf mevcutlarının kalabalık olmasına neden olmaktadır. Öğrenci sayısının artması ise eğitimin niteliğinde yeni sorunlara neden olmaktadır (Kalemoğlu-Varol ve İmamoğlu, 2014). Öğrenci sayısı ile yakından ilişkili bir diğer etken de öğretmen başına düşen öğrenci sayısıdır. Sınıftaki öğrenci sayısı arttıkça, öğretmenin işyükü de artmakta ve daha çok öğrencinin başarısından sorumlu olmaktadır. 
Genel olarak öğrenci başarısıyla ilgili araştırmaların sonuçları değerlendirildiğinde, başarıyı etkileyen etmenlerin biribirinden bağımsız ele alınamayacak yapılar olduğu görülmektedir. Eğitimle ilgili araştırmalardan elde edilen bu veriler sıradizinsel yapıdadır (Noyan, 2009). Siradizinsel yapıdaki veri setinde gözlemlerin birbirine bağımlı olması nedeniyle tek düzeyli analiz yöntemlerinin kullanılması istatistiksel ve kavramsal sorunlara yol açmaktadır (Hox, 2010). Sıradizinsel yapıdaki verilerin analizinde birleştirme (aggregation), ayrıştırma (disaggregation) ve çok düzeyli modeller olmak üzere üç farklı yöntem kullanılmaktadır (Stapleton, 2006). Birey düzeyi gözardı edilip grup üzerinden analiz yapılan birleştirme (aggregate) yaklaşımında veri sayısı grup sayısı kadar olacağından, gruplararası değişim araştırılır (Can, 2012). Grup sayısı, birey düzeyindeki gözlem sayısından daha az olacağından, büyük bir veri kaybı söz konusu olur ve yapılan istatistiksel testlerin de gücü azalır. Grupiçi değişim (varyans) analize dahil edilemediğinden, grup farklılıkları da olduğundan daha yüksek tahminlenecektir (Heck, 2001; Kaplan ve Elliot, 1997). Öğrenci düzeyindeki varyans göz ardı edilip, sınıf düzeyinden öğrenci düzeyine ilişkin çıkarımlar yapmak da hatalı olacaktır. Alanyazında bu durum ekolojik yanilgi (ecological fallacy) ya da Robinson etkisi olarak anılmaktadır. Robinson'un (1950), dokuz farklı bölgedeki siyahilerin yüzdesi ile cehalet yüzdesi arasındaki ilişkiyi araştırdığı çalışmada, siyahilerin yüzdesi ile cehalet yüzdesi arasında grup üzerinden hesaplanan korelasyon .95, bireyler üzerinden hesaplanan korelasyon ise .20 olarak bulunmuştur (akt., Hox, 2010).

Birden çok düzeye sahip modeller sıradizinsel yapıdaki verinin her bir düzeyindeki değişkenler arasındaki ilişkilerin eşzamanlı olarak ele alınmasını sağlar. Böylece tek başına öğrenci ya da sınıf analizi yapıldığında karşılaşılan istatistiksel ve kavramsal problemleri ortadan kaldırır (Heck, 2001). Sosyal bilim alanında yapılan çalışmalarda hipotezlerin test edilmesi aşamasında sıklıkla hem çok düzeyli hem de çok değişkenli veriler birlikte kullanıldığından, her iki modellemenin birlikte kullanılması ihtiyacı ortaya çıkmışıı (Bentler ve Liang, 2003; Kaplan ve Elliot, 1997). Çünkü veri çok düzeyli olduğunda araştırılan konunun analizinde yalnızca yapısal eşitlik modelinin kullanılması, verilerin hiyerarsik yapısının göz ardı edilmesine, dolayısıyla yanlı kestirimlerin elde edilmesine neden olmaktadır (Muthen ve Muthen, 1998). Yalnızca çok düzeyli modellerin kullanımı ise değişkenler arasındaki dolaylı ilişkilerin araştırılmasını yetersiz kılmaktadır. Böylece sıradizinsel verinin her bir düzeyinde (birey ve grup düzeyi) eşzamanlı testlere imkan veren birden çok düzeye sahip yapısal eşitlik modellemeleri ile çözümlemeler yapılmaya başlanmıştır.

Yapılan literatür taraması sonucunda eğitim alanında öğrenci başarısı ile ilişkili sıradizinsel yapıdaki verilerin kullanıldığı çalışmaların yaygınlaştığı ve genel olarak çok düzeyli modellerin bir türü olan sıradizinsel lineer modellerin kullanıldığ 1 görülmektedir (Demir ve Kılıç, 2010; Şimşek ve Noyan, 2009; Usta, 2014; Yıldırım, 2012). Ancak gizil değişkenlerin modele eklenmesinde yaşanan sorunlar ve karmaşı yol analizleri yapılamaması gibi sınırlılıkları bulunmaktadır (Bauer, 2003). Oysa değişkenler arasında doğrudan etkilerin yanı sıra dolaylı etki olarak adlandırılan 
ilişkilerin de incelenmesi, değişkenlerin birbirleri ile bağıntılarının nedenlerinin anlaşılması açısından önemlidir. Sıradizinsel lineer modellerin bu sınırlılığı akademik başarı ile ilişkili okul, aile ve öğrenci özelliklerinin doğrudan ve dolaylı etkilerinin hem grupiçi hem de gruplararası düzeyde eşzamanlı olarak çok düzeyli yapısal eşitlik modellemesi ile incelenmesini önemli kılmakta ve bu araştırmanın problemini oluşturmaktadır.

\section{Araştırmanın Amacı}

Bu araştırmada 6, 7 ve 8. sınıfa devam eden öğrencilerin akademik başarıları ile ailelerinin sosyo ekonomik özellikleri, akademik ortamlarda olumsuz değerlendirilme korkusu, akademik risk alma davranışları, sınıf öğrenci sayısı ve öğretmen başına düşen öğrenci sayısı değişkenleri arasındaki çok düzeyli yapısal ilişkiyi ortaya koymak amaçlanmıştır. Bu nednele aşağıdaki sorular yanıtlanmıştır:

1. Araştırmada yer alan okulların akademik başarıları arasında manidar fark var midir?

2. Grupiçi (öğrenci) düzeyde akademik başarıy1; öğrencilerin sosyoekonomik düzeyleri, olumsuz değerlendirilme korkusu ve akademik risk alma davranışı, gruplararası (okul) düzeyde sınıf öğrenci sayısı ve öğretmen başına düşen öğrenci sayısı ne düzeyde açıklamaktadır?

\section{Yöntem}

Bu bölümde araştırma modeline, araştırma grubunun özelliklerine, veri toplama araç ve yöntemlerine ve verilerin analizine ilişkin bilgilere yer verilmiştir.

\section{Araştırma Modeli}

$\mathrm{Bu}$ araştırmada akademik başarının aile, öğrenci ve okul özellikleri ile iliş̧isi incelendiğinden doğrudan ve dolaylı etkilerin testlerine dayalı yordayıcı korelasyonel araştırma deseni kullanılmıştır. Yordayıcı korelasyonel araştırma deseni, bir değişkene ilişkin bilinmeyen bazı değerlerin yordayıcı olarak adlandırılan diğer değişkenlerden kestirilerek ortaya çıkarılmasının amaçlandığı araştırmalarda kullanılmaktadır (Creswell, 2008).

\section{Evren-Örneklem}

Bu araştırmanın evrenini, Ankara ili Çankaya, Keçiören, Altındağ, Mamak ve Yenimahalle ilçelerinde bulunan ortaokullarda öğrenim gören 6,7 ve 8 . Sınıf öğrencileri oluşturmaktadır. Çalışma bu evrenden seçilen örneklem üzerinde gerçekleştirilmiştir. Çalışmada amaçsal örnekleme yöntemi ve bu yöntemin bir türü olan maksimum çeşitlilik örnekleme stratejisi kullanılmıştır. Tablo 1'de ise örnekleme giren öğrencilerin ilçelere, sınıf düzeylerine ve cinsiyete göre dağılımı verilmiş̧ir. 
Tablo 1

Örnekleme Giren Öğrencilerin İlçelere, Sınıf Düzeylerine ve Cinsiyete Göre Dağılımı

\begin{tabular}{|c|c|c|c|c|c|c|c|c|c|}
\hline \multicolumn{10}{|c|}{ Sınıf Düzeyi } \\
\hline \multirow[t]{2}{*}{ İlçe } & \multirow[t]{2}{*}{ Cinsiyet } & \multicolumn{2}{|c|}{ 6. Sinıf } & \multicolumn{2}{|c|}{ 7. Sinıf } & \multicolumn{2}{|c|}{ 8. Sinıf } & \multicolumn{2}{|c|}{ Toplam } \\
\hline & & f & $\%$ & f & $\%$ & f & $\%$ & f & $\%$ \\
\hline \multirow[t]{2}{*}{ Çankaya } & K1z & 144 & 33.33 & 145 & 33.56 & 143 & 33.10 & 432 & 13.63 \\
\hline & Erkek & 159 & 38.41 & 132 & 31.88 & 123 & 29.71 & 414 & 13.06 \\
\hline \multirow{2}{*}{ Keçiören } & $\mathrm{K} 1 \mathrm{z}$ & 115 & 32.39 & 128 & 36.06 & 112 & 31.55 & 355 & 11.20 \\
\hline & Erkek & 128 & 34.22 & 114 & 30.48 & 132 & 35.29 & 374 & 11.80 \\
\hline \multirow[t]{2}{*}{ Mamak } & K1z & 82 & 33.20 & 88 & 35.63 & 77 & 31.17 & 247 & 7.79 \\
\hline & Erkek & 84 & 37.84 & 66 & 29.73 & 72 & 32.43 & 222 & 7.00 \\
\hline \multirow[t]{2}{*}{ Altındağ } & $\mathrm{K} 1 \mathrm{z}$ & 91 & 30.95 & 112 & 38.10 & 91 & 30.95 & 294 & 9.27 \\
\hline & Erkek & 106 & 33.65 & 96 & 30.48 & 113 & 35.87 & 315 & 9.94 \\
\hline \multirow[t]{2}{*}{ Ymahalle } & $\overline{\mathrm{K}} 1 \mathrm{z}$ & 76 & 29.69 & 84 & 32.81 & 96 & 37.50 & 256 & 8.08 \\
\hline & Erkek & 96 & 36.78 & 91 & 34.87 & 74 & 28.35 & 261 & 8.23 \\
\hline \multirow[t]{2}{*}{ Toplam } & $\mathrm{K} 1 \mathrm{z}$ & 508 & 32.07 & 557 & 35.16 & 519 & 32.77 & 1584 & 49.97 \\
\hline & Erkek & 573 & 36.13 & 499 & 31.46 & 514 & 32.41 & 1586 & 50.03 \\
\hline Toplam & & 1081 & 34.10 & 1056 & 33.31 & 1033 & 32.59 & 3170 & 100 \\
\hline
\end{tabular}

Tablo 1'de görüldüğü gibi araştırmada yer alan toplam 3170 öğrencinin 846's1 (\% 26.69) Çankaya'daki ortaokullarda, 729'u (\% 23) Keçiören'deki ortaokullarda, 469'u (\% 14.79) Mamak'taki ortaokullarda, 609'u (\% 19.21) Altındağ'daki ortaokullarda, 517'si (\% 16.31) ise Yenimahalle'deki ortaokullarda öğrenimlerine devam etmektedir. Öğrencilerin 1584'ü (\% 49.97) kız, 1586’s1 (\% 50.03) erkektir. Araştırmaya katılan öğrencilerin 1081'i (\% 34.10) 6. Sınıfta, 1056'sı (\% 33.31) 7. Sınıfta ve 1033 'ü (\% 32.59) 8. sinıfta öğrenim görmektedir.

\section{Veri Toplama Araci}

Araştırmada araştırmacı tarafindan hazırlanan Öğrenci Bilgi Anketi, olumsuz değerlendirilme korkularını belirlemek amacıyla ise Alkan (2015) tarafindan geliştirilen Akademik Ortamlarda Olumsuz Değerlendirilme Korkusu Ölçeği ve Clifford (1991) tarafından geliştirilmiş, uyarlaması Korkmaz (2002) tarafından yapılmış Akademik Risk Alma Ölçeği kullanılmıştır.

Öğrenci bilgi anketi. Araştırmacı tarafından hazırlanmıştır. Anket; öğrenim görülen okul, okul türü, sınıf düzeyi, cinsiyet, akademik başarı not ortalaması, kardeş sayısı, gelir düzeyi, ebeveyn eğitim durumu ve okula bağlılık düzeyi hakkında bilgileri içeren kapalı uçlu maddelerden oluşturulmuştur.

Akademik ortamlarda olumsuz değerlendirilme korkusu ölçeği. Alkan (2015) tarafindan geliştirilmiştir. Akademik Ortamlarda Olumsuz Değerlendirilme Korkusu Ölçeği (AOODK) 6., 7. ve 8. sınıf öğrencilerinin akademik ortamlarda yaşadıkları olumsuz değerlendirilme korkusunu ölçmek amacıyla geliştirilmiştir. Olumsuz Değerlendirilme Korkusunun Davranışsal Etkileri ve Olumsuz Değerlendirilme Korkusunun Bilişsel Etkileri olmak üzere iki ayrı boyuttan oluşan 
ölçekte toplam 22 madde yer almaktadır. Bu maddelerin 12'si Olumsuz Değerlendirilme Korkusunun Davranısssal Etkileri alt boyutunda, 10'u Olumsuz Değerlendirilme Korkusunun Bilişsel Etkileri alt boyutunda yer almaktadır. Akademik Ortamlarda Olumsuz Değerlendirilme Korkusu Ölçeği'nin Cronbach alfa iç tutarlılık katsayısı birinci faktör (olumsuz değerlendirilme korkusunun davranışsal etkileri) için .912, ikinci faktör (olumsuz değerlendirilme korkusunun bilişsel etkileri) için .744 ve ölçeğin tamamı için .907'dir. Elde edilen Cronbach alfa katsayıları hem faktörlerin, hem de ölçeğin iç tutarlık anlamında güvenirliğinin yeterli düzeyde olduğunu göstermektedir.

Akademik risk alma ölçeği. Akademik Risk Alma Ölçeği, Clifford (1991) tarafından ortaokul öğrencilerinin eğitim ortamlarında karşılaştıkları zorluklarla başedebilme becerisini ve çabasını ölçmek amacıyla geliştirilmiştir. Ölçeğin orjinali Başarısızlık Sonrası Olumsuz Düşüncelere Sahip Olma Eğilimi (BSODS), Zor İşlemleri Tercih Etme Ĕ̈ilimi (ZïTE) ve Başarısızlık Ardından Tekrar Toparlanma ve Sürece Etkin Katılma Eğilimi (BATSEK) olmak üzere üç ayrı boyuttan oluşmakta, ölçekte toplam 36 madde yer almaktadır. Akademik Risk Alma Ölçeği, Korkmaz (2002) tarafindan Türkçeye uyarlanmıştır. Korkmaz (2002) tarafindan yapılan uyarlama çalışmasında Ödev Yapmama Eğilimi (ÖYE) olarak adlandırılan dördüncü bir boyut belirlenmiştir. Uyarlama çalışması sonucunda, BSODS boyutunda 11 madde, ZITE boyutunda 10 madde, BATSEK boyutunda 12 madde, ÖYE boyutunda ise 3 madde yer almaktadır. Akademik Risk Alma Ölçeği'nin Cronbach alfa iç tutarlılık katsayısı birinci faktör için .65, ikinci faktör için .78, üçüncü faktör için .84 , dördüncü faktör için .50 ve ölçeğin tamamı için .91 'dir. Elde edilen Cronbach alfa katsayıları 1. ve 4. faktör için orta düzeyde, 2. ve 3. faktör için güvenirliğin yeterli düzeyde olduğunu göstermektedir.

\section{Verilerin Analizi}

Araştırmada kullanılacak Çok Düzeyli Yapısal Eşitlik Modeli analizinin varsayımlarının sinanması ve betimsel istatistiklerin belirlenmesinde IBM SPSS 20 programı, oluşturulan çok düzeyli yapısal modellerin analizinde ise Mplus 7.0 programı kullanılmıştır. Ölçme modeli doğrulanmadan yapısal modeli test etmek anlamlı olmayacağı için önce ölçme modelleri test edilmiştir.

Varsayımların sınanması. Verilerden geçerli sonuçların çıkartılabilmesi ve kestirilen parametrelerin yansız bir şekilde değerlendirilebilmesi için öncelikle veri seti Kayıp Veriler, Örneklem Büyüklüğ̈̈ ve Uç Değerler açısından incelenip gerekli düzenlemeler yapılmıştır. Daha sonra Çok Düzeyli Yapısal Eşitlik Modelleri için gerekli olan Çok Değişkenli Normallik, Çoklu Doğrusallık ve Çoklu Bağlantı varsayımları test edilmiştir. 10 katılımcıya ait verilerde kayıp değere rastlanmış, bu deneklere ait veriler liste bazında silme yöntemi ile analiz dışı bırakılmıştır. grupiçi örneklem büyüklügü 3109 , gruplararası örneklem büyüklüğü ise $35^{\prime}$ tir. Çok düzeyli yapısal eşitlik modelini test etmek için gerekli örneklem büyüklüğü varsayımı karşılanmaktadır. $\mathrm{Bu}$ araştırmada tek değiş̧kenli uç değerleri belirlemek amacıyla ham veriler standart $Z$ puanlarına dönüştürülmüşs, -3 ve +3 aralığının dışında kalan hiçbir 
değere rastlanmamıştır. $\mathrm{Bu}$ araştırma verileri için çoklu bağlantı sorununun incelenmesi sonucunda verilere ilişkin VIF değerlerinin 1.9 ile 6.5 arasında değiştiği, tolerans değerlerinin ise 0.10 'dan büyük olduğu gözlenmiştir. Bu değerler ile değişkenler arasında çoklu bağlantı probleminin olmadığı sonucuna ulaşılmıştır.

Ölçme modellerinin oluşturulması. Öğrenci düzeyinde yer alan sosyoekonomik düzey, olumsuz değerlendirilme korkusu ve akademik risk alma davranışı gizil değişkenleri ve onlara ait gözlenen değişkenler ile kurulan ölçme modeline ilişkin uyum iyiliği indeksleri Tablo 2'de verilmiştir.

Tablo 2

Ölçme Modeli Uyum Indeksleri

\begin{tabular}{clllll}
\hline \multicolumn{1}{c}{$\boldsymbol{X}^{\mathbf{2}}$} & $\boldsymbol{X}^{\mathbf{2}} / \mathbf{s d}$ & RMSEA & CFI & TLI & SRMR \\
\hline $156.740^{*}$ & 3.26 & .07 & .943 & .914 & .027 \\
\hline${ }^{\mathrm{p}}<.05$ & & & & &
\end{tabular}

Tablo 2 incelendiğinde $\mathrm{X}^{2} / \mathrm{sd}$ oranının 5 'in altında olması, RMSEA değerinin .08'e eşit ya da küçük olması, CFI ve TLI değerlerinin .90'nı aşması veri ile model arasındaki uyumun iyi olduğunu göstermektedir (Heck ve Thomas, 2015; Thompson, 2000). Ölçme modeline dahil edilen gizil değişkenlere ait gözlenen değişkenlerin standartlaştırılmış faktör yükleri, hata varyansları ve açıkladıkları varyanslara ait bilgiler Tablo 3'te sunulmuştur.

Tablo 3

Ölçme Modeli Standartlaştırılmış Faktör Yükleri

\begin{tabular}{|c|c|c|c|c|c|c|}
\hline $\begin{array}{l}\text { Gizil } \\
\text { Değişken }\end{array}$ & $\begin{array}{l}\text { Gözlenen } \\
\text { Değişkenler }\end{array}$ & $\begin{array}{l}\text { Standartlaştırılmış } \\
\text { Faktör Yükleri }\end{array}$ & $\mathbf{p}$ & $R^{2}$ & $\begin{array}{l}\text { Hata } \\
\text { Varyansları }\end{array}$ & $\alpha$ \\
\hline \multirow{3}{*}{ SED } & Anne Eğitim & .668 & .000 & .446 & .554 & \multirow{3}{*}{.77} \\
\hline & Baba Eğitim & .676 & .000 & .456 & .544 & \\
\hline & $\begin{array}{l}\text { Ailenin } \\
\text { Geliri }\end{array}$ & .662 & .000 & .439 & .561 & \\
\hline \multirow{2}{*}{ ODK } & ODK_BİL & .923 & .000 & .877 & .123 & \multirow{2}{*}{.76} \\
\hline & ODK_DAV & .937 & .000 & .852 & .148 & \\
\hline \multirow{4}{*}{ ARA } & BSODS & .847 & .000 & .717 & .283 & \multirow{4}{*}{.89} \\
\hline & ZİTE & .903 & .000 & .815 & .185 & \\
\hline & BATSEK & .937 & .000 & .879 & .121 & \\
\hline & OYE & .690 & .000 & .476 & .524 & \\
\hline
\end{tabular}

Tablo 3 incelendiğinde Sosyoekonomik Düzey (SED) değişkenine ilişkin faktör yükleri .662 ile .676 arasında; Olumsuz Değerlendirilme Korkusu (ODK) değişkenine ilişkin faktör yükleri .923 ile .937 arasında, Akademik Risk Alma (ARA) değişkeninin faktör yükleri .690 ile .937 arasında değişmektedir $(p<.05)$. Söz konusu gözlenen değişkenlere ilişkin standartlaştırılmış faktör yüklerinden hiçbirinin 1 'den büyük 
olmadığı görülmektedir. Sosyoekonomik düzey faktörüne ait değişkenliğin en çok baba ĕgitim düzeyi tarafından açıklandığı görülmektedir $\left(\mathrm{R}^{2}=.456\right)$. Olumsuz değerlendirilme korkusu faktörüne ilişkin değişkenlik en çok olumsuz değerlendirilme korkusunun bilişsel etkileri $\left(\mathrm{R}^{2}=.877\right)$, akademik risk alma faktörüne ilişkin değişkenlik en çok, başarısızlığın ardından tekrar toparlanma ve sürece etkin katılma eğilimi $\left(\mathrm{R}^{2}=.879\right)$ gözlenen değişkeni tarafindan açıklanmaktadır. Tablo 3 'te belirtildiği gibi sosyoekonomik düzey, olumsuz değerlendirilme korkusu ve akademik risk alma değişkenlerinin güvenirlik katsayıları .76 ile .89 arasında değişmektedir. Bu değerlerin en az .60 olması her alt ölçeğin güvenilir olduğu anlamına gelmektedir (Kalayc1, 2006).

Çok düzeyli yapısal eşitlik modellerinin oluşturulması. Araştırmanın alt amaçları doğrultusunda iki model test edilmiştir. Her alt amaçta yer alan araştırma sorusuna yanıt bulmak amacıyla grupiçi ve gruplararası düzeyde yer alan değişkenler arasındaki ilişkiler teoriye dayandırılarak modeller tanımlanmıştır. Her alt amaca ilişkin kurulan modeller ve modellerin açıklamaları aşağıda alt amaç sırasına göre sunulmuştur.

Tek yönlü ANOVA modeli. Birinci alt amaç olan Çalışma grubunda yer alan okulların akademik başarıları arasında fark var mıdır? sorusunu cevaplamak amaciyla tek yönlü ANOVA modeli oluşturulmuştur. Şekil 1'de gösterilen bu model, akademik başarı gözlenen değişkenini grupiçi (öğrenci) ve gruplararası (okul) varyans bileşenlerine ayırarak çok düzeyli analiz yapılmasına gerek olup olmadığı konusunda bilgi verir. Tek Yönlü ANOVA modelinde sınıfiçi korelasyon katsayıs hesaplanarak, sonuca ilişkin değişkenliğgin ne kadarına gruplararası ve grupiçi düzeyin yol açtığı belirlenebilir (Raudenbush ve Bryk, 2002).

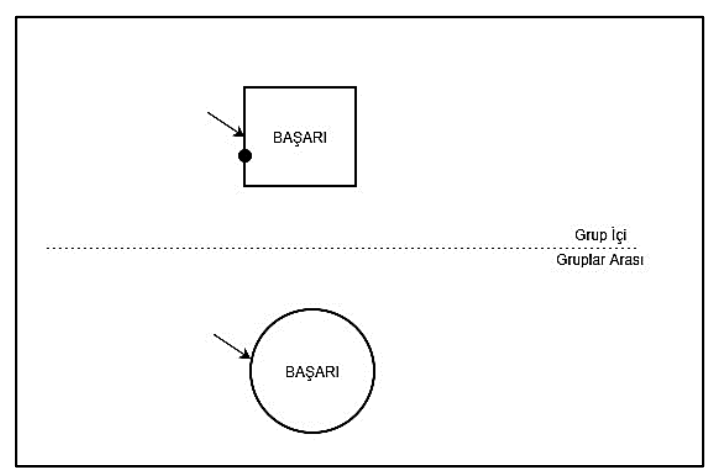

Şekil 1. Tek yönlü ANOVA modeli

Grupiçi ve gruplararası düzeyde akademik başarıyı açıklayan model. Şekil 2'de gösterilen model ile ikinci araştırma sorusu olan Grupiçi düzeyde (öğrenci) sosyoekonomik düzey, olumsuz değerlendirilme korkusu ve akademik risk alma 
davranışının, gruplararası düzeyde (okul) ise sınıf ögrenci sayısı ve öğretmen başına düşen öğrenci sayısının akademik başarı ile olan yapısal ilişkisi ne düzeydedir? sorusuna yanıt bulmak amaçlanmıştır.

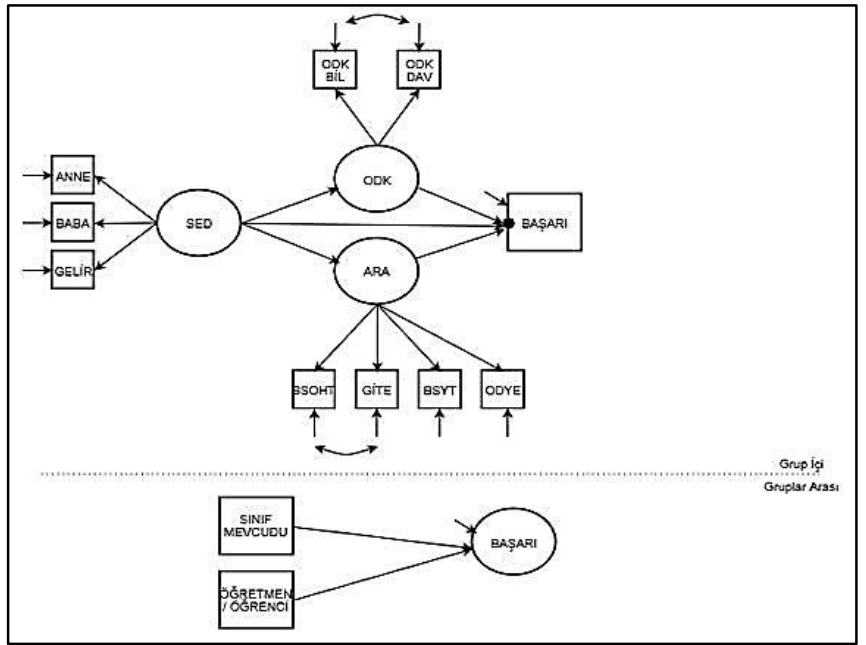

Şekil 2. Grupiçi ve gruplararası düzeyde akademik başarıyı açıklayan model

Şekil 2'de gösterilen modelde grupiçi (öğrenci) düzeyde öğrencilerin akademik başarıları ile öğrencilerin olumsuz değerlendirilme korkusu, akademik risk alma davranışı ve sosyoekonomik düzeyleri yer almaktadır. Gruplararası (okul) düzeyde ise grupiçinde yer alan akademik başarı gözlenen değişkeninin seçkisiz kesişimi ile sınıf öğrenci sayısı ve öğretmen başına düşen öğrenci sayısı gözlenen değişkenleri yer almaktadır. Şekil 1 ve 2'de gösterilen modeller test edilmiş, bulgular aşağıda sunulmuştur.

\section{Bulgular}

$\mathrm{Bu}$ bölümde araştırmanın amacı doğrultusunda elde edilen bulgular ve bu bulgulara dayalı yorumlar sunulmuştur.

\section{Araştırmada Yer Alan Okulların Akademik Başarılarının Karşıllaştırılmasına İlişkin Bulgular}

Araştırmanın birinci alt amacı doğrultusunda araştırmaya katılan okulların akademik başarıları arasında manidar fark bulunup bulunmadığının belirlenmesi için öğrencilerin akademik başarı puanlarına ilişkin sınıfiçi korelasyon katsayıları hesaplanmıştır. Akademik başarıya ilişkin sınıfiçi korelasyon katsayısı $p=.29$ bulunmuştur. Buna göre öğrencilerin akademik başarılarındaki farklılıkların \% 29'u okullararası farklılıklardan, \% 71’i ise aynı okulda öğrenim gören öğrenciler 
arasındaki farklılıklardan kaynaklanmaktadır. Sınıfiçi korelasyon katsayısının .05’ten büyük olması, analizin çok düzeyli yapısal eşitlik modeli ile yapılmasını gerekli k1lmaktadır (Heck, 2001).

\section{Grupiçi ve Gruplararası Düzeyde Akademik Başarıyı Açıklayan Değişkenlere İlișkin Bulgular}

Araştırmanın ikinci alt amacı doğrultusunda grupiçi (öğrenci) düzeyde akademik başarıy1, öğrencilerin sosyoekonomik düzeyleri, olumsuz değerlendirilme korkusu ve akademik risk alma davranışı, gruplararası (okul) düzeyde ise sınıf öğrenci sayısı ve öğretmen başına düşen öğrenci sayısının ne düzeyde açıkladığının belirlenmesi için grupiçi ve gruplararası düzey eşzamanlı olarak test edilmiştir.

\section{Tablo 4}

Grupiçi ve Gruplararası Düzeyde Akademik Başarıyı Açıklayan Değişkenlere İlişskin Kurulan Modelin Uyum Iyiliği Istatistikleri

\begin{tabular}{llccll}
\hline$X^{2}$ & RMSEA & CFI & TLI & $\begin{array}{l}\text { SRMR } \\
\text { (grupiçi) }\end{array}$ & $\begin{array}{l}\text { SRMR } \\
\text { (gruplararası) }\end{array}$ \\
\hline $359.648^{*}$ & .059 & .989 & .983 & 0.021 & 0.000 \\
\hline
\end{tabular}

*p $<.05$

Tablo 4 incelendiğinde, öğrenci (grupiçi) ve okul (gruplararası) eşzamanlı olarak test edilen kuramsal modelin ki-kare değeri manidar bulunmuştur $\left(\chi_{(30)}^{2}=359.648 p<\right.$ 0.05). Ancak model MLR yöntemi ile kestirildiğinden ki-kare değeri model iyiliği uyumu indeksi olarak değerlendirilmemektedir. Bu nedenle diğer model uyum indeksleri incelenmektedir. Analiz sonucunda RMSEA değeri 059 olarak bulunmuştur. $\mathrm{Bu}$ değer model parametrelerinin evren kovaryansları ile iyi uyum gösterdiği şeklinde yorumlanabilir. Analiz sonucunda CFI değeri .989, TLI değeri ise .983 olarak bulunmuştur. $\mathrm{Bu}$ değerler de, modelin iyi uyuma sahip olduğunu belirlemek için yeterlidir. Grupiçi ve gruplararası model veri uyumunu ayrı ayrı belirten SRMR indeksleri incelendiğinde grupiçi düzeyde SRMR .021, gruplararası düzeyde ise .000 'dır. SRMR değerlerine göre hem grupiçi düzeyde hem de gruplararası düzeyde model veri uyumunun iyi olduğu görülmektedir. Model gruplararası düzeyde grupiçi düzeye göre daha yüksek uyum iyiliği göstermektedir.

Model uyumunun iyi ya da kabul edilebilir düzeyde olduğuna karar verdikten sonra kestirilen parametre değerleri incelenmelidir. Tablo 5 'te verilen parametrelerin standartlaştırılmamış değerlerinin yorumlanması zor olmasından ve farklı metriklerle ölçülen değişkenlerin faktör yükleri ve hata varyansları karşılaştırma açısından standardize edilmiş parametre değerlerinin (STDYX) yorumlanması önerilir (Heck ve Thomas, 2015). 
Tablo 5

Grupiçi ve Gruplararası Düzeyde Akademik Başarıyı Açıklayan Değişkenlerle Kurulan Kuramsal Modelin Kestirilen Parametre Değerleri

\begin{tabular}{|c|c|c|c|c|c|c|c|}
\hline Düzey & Değişken & Komut & $\boldsymbol{\beta}$ & $\begin{array}{l}\text { St. } \\
\text { Hata }\end{array}$ & $\mathbf{t}$ & $\mathbf{p}$ & BSTDYX \\
\hline \multicolumn{8}{|l|}{ Grup İçi } \\
\hline \multirow[t]{4}{*}{ SED } & & BY & & & & & \\
\hline & ANNE E & & 1.000 & 0.000 & 999.000 & 999.000 & 0.718 \\
\hline & BABA E & & 1.069 & 0.029 & 36.322 & 0.000 & 0.756 \\
\hline & GELIR & & 0.941 & 0.039 & 23.985 & 0.000 & 0.698 \\
\hline \multirow[t]{3}{*}{ ODK } & & BY & & & & & \\
\hline & ODKBİL & & 1.000 & 0.000 & 999.000 & 999.000 & 0.943 \\
\hline & ODKDAV & & 1.005 & 0.009 & 111.766 & 0.000 & 0.942 \\
\hline \multirow[t]{5}{*}{ ARA } & & BY & & & & & \\
\hline & BSODS & & 1.000 & 0.000 & 999.000 & 999.000 & 0.880 \\
\hline & ZİTE & & 1.230 & 0.019 & 65.355 & 0.000 & 0.925 \\
\hline & BATSEK & & 1.441 & 0.025 & 58.588 & 0.000 & 0.948 \\
\hline & OYE & & 0.278 & 0.006 & 45.116 & 0.000 & 0.730 \\
\hline \multirow[t]{2}{*}{ ODK } & & $\mathrm{ON}$ & & & & & \\
\hline & SED & & -7.014 & 0.324 & -21.670 & 0.000 & -0.734 \\
\hline \multirow[t]{2}{*}{ ARA } & & $\mathrm{ON}$ & & & & & \\
\hline & SED & & 5.175 & 0.355 & 14.584 & 0.000 & 0.830 \\
\hline \multirow[t]{4}{*}{ BAŞARI } & & $\mathrm{ON}$ & & & & & \\
\hline & SED & & 2.094 & 0.571 & 3.667 & 0.000 & 0.133 \\
\hline & ARA & & 1.054 & 0.066 & 15.942 & 0.000 & 0.416 \\
\hline & ODK & & -0.786 & 0.047 & -16.780 & 0.000 & -0.476 \\
\hline \multicolumn{8}{|c|}{ Hata Varyansları } \\
\hline & ANNE E & & 0.824 & 0.045 & 18.292 & 0.000 & 0.484 \\
\hline & BABA E & & 0.754 & 0.063 & 12.043 & 0.000 & 0.429 \\
\hline & GELİR & & 0.817 & 0.044 & 18.360 & 0.000 & 0.512 \\
\hline & ODKBİL & & 10.280 & 0.728 & 14.114 & 0.000 & 0.112 \\
\hline & ODKDAV & & 10.017 & 0.656 & 15.278 & 0.000 & 0.111 \\
\hline & BSODS & & 9.961 & 0.394 & 25.288 & 0.000 & 0.226 \\
\hline & ZİTE & & 8.731 & 0.412 & 21.206 & 0.000 & 0.144 \\
\hline & BATSEK & & 7.942 & 0.395 & 20.129 & 0.000 & 0.101 \\
\hline & OYE & & 2.312 & 0.057 & 40.902 & 0.000 & 0.468 \\
\hline & BAŞARI & & 22.158 & 1.264 & 17.527 & 0.000 & 0.101 \\
\hline \multicolumn{8}{|c|}{ Gruplararası } \\
\hline \multirow[t]{5}{*}{ BAŞARI } & & $\mathrm{ON}$ & & & & & \\
\hline & SINIF & & -0.412 & 0.143 & -2.889 & 0.004 & -0.439 \\
\hline & ÖĞRENCİ & & & & & & \\
\hline & SAYISI & & & & & & \\
\hline & $\begin{array}{l}\text { ÖĞRETMEN/ } \\
\text { ÖĞRENCİ }\end{array}$ & & -0.567 & 0.228 & -2.485 & 0.013 & -0.348 \\
\hline \multicolumn{8}{|c|}{ Hata Varyansları } \\
\hline & GBAŞARI & & 40.221 & 7.741 & 5.196 & 0.000 & 0.601 \\
\hline
\end{tabular}


Tablo 5'te gösterilen BY komutu gizil değiş̧kenlere ait gözlenen değişkenleri temsil etmektedir. ON komutu ise değişkenler arasındaki doğrudan ilişkileri göstermektedir. Tablo 5'te verilen değişkenlere ilişkin standartlaştırılmış faktör yükleri incelendiğinde sosyoekonomik düzeye ilişkin faktör yüklerinin anne eğitim düzeyi için 0.644 , baba eğitim düzeyi için 0.683 , ailenin aylık ortalama geliri için 0.681 olduğu görülmektedir. Olumsuz değerlendirilme korkusuna ilişkin faktör yüklerinin olumsuz değerlendirilme korkusunun bilişsel boyutu için 0.745 , davranışsal boyutu için 0.923, akademik risk alma davranışına ilişkin faktör yüklerinin BSODS için 0.878, ZITE için 0.924, BATSEK için 0.951 ve OYE için 0.730 olduğu ve değiş̧kenlere ilişkin tüm faktör yüklerinin istatistiksel olarak manidar olduğu görülmektedir $(\mathrm{p}<.05)$.

Tablo 5 incelendiğinde hem grupiçi hem de gruplararası düzeyde, bağımsız değişkenlerden bağımlı değişkenlere olan doğrudan etkilerin tümünün manidar olduğu görülmektedir $(\mathrm{p}<.05)$. Grupiçi (öğrenci) düzeyde Olumsuz Değerlendirilme Korkusu değiş̧keninin Akademik Başarı değişkenine ve Sosyoekonomik Düzey değişkeninin Olumsuz Değerlendirilme Korkusu değişkenine doğrudan etkisi negatif yöndeyken, diğer değişkenler arasındaki doğrudan etkilerin tümü pozitif yöndedir. Gruplararası düzeyde Sinı Öğrenci sayısı ve Öğretmen Başına Düşen Öğrenci Sayısı değişkenlerinin Akademik Başarı değişkenine doğrudan etkisi ise negatif yöndedir.

Standartlaştırılmış yol katsayıları $|0.10|$ 'dan küçük ise zayıf etki, $|0.30|$ değerine yakınsa orta etki ve $|0.50|$ 'den büyükse güçlü bir etkiye sahip olarak yorumlanır (Cohen, 1992; Kline, 2005). Bu referans aralıklarına göre modelde yer alan yapısal ilişkiler incelendiğinde, grupiçi düzeyde (öğrenci) sosyoekonomik düzey ile akademik başarı değişkeni arasındaki standartlaştırılmış yol katsayısı $\beta=0.133(p<$ .05 ) olarak bulunmuștur. Buna göre grupiçi düzeyde öğrencilerin akademik başarıları üzerinde sosyoekonomik düzeyin doğrudan etkisi zayıf düzeydedir. Sosyoekonomik düzeydeki bir birimlik artış akademik başarıda 0.13 birimlik bir artışa neden olmaktadır. Araştırmanın bu bulgusu alanyazında sosyoekonomik düzey ile akademik başarı arasındaki ilişkiyi araştıran çalışmaların sonuçları ile benzerdir. Alivernini ve Manganelli (2015) tarafından yapılan çalışmada, okuma başarısı üzerinde sosyoekonomik düzeyin etkileri araştırılmış, grupiçi (öğrenci) düzeyde, sosyoekonomik düzeyin okuma başarısı üzerinde doğrudan etkisinin olduğu, sosyoekonomik düzeydeki bir birimlik artışın, okuma başarısında 0.38 'lik bir artışa neden olduğu, grupiçi düzeyde başarıdaki değişkenliğgin \% 16'sının sosyoekonomik düzey değişkeni ile açıklandığı belirlenmiştir. Aynı çalışmada gruplararası düzeyde okulların sosyoekonomik düzeylerinin okuma başarıları üzerinde doğrudan etkisinin manidar olduğu sonucuna ulaşılmıştır. Gruplararası düzeyde sosyoekonomik düzeydeki bir birimlik artış, okulların okuma başarılarında 0.34 'lük bir artışa neden olmaktadır. Okullar düzeyinde başarıdaki değişkenliğin $\% \quad 31$ 'i okulların sosyoekonomik düzeyi ile açıklanmaktadır. Özer ve Anıl (2011) yaptıkları çalışmada fen bilimleri başarısı üzerinde ailenin sosyoekonomik özelliklerinin doğrudan etkisi olduğu sonucuna ulaşılmıştır. Ailenin sosyoekonomik özelliklerindeki bir birimlik artış, fen bilimleri başarısında $0.16^{\prime}$ lık bir artışa neden olmaktadır. Sosyoekonomik 
düzeyi yüksek olan aileler, çocuklarına daha fazla ekonomik, sosyal ve eğitsel olanak sağlamakta ve bu durum akademik başarılarını pozitif olarak etkilemektedir (Ergün, 1992; Gregg ve Machin, 1998; McNeal, 1999).

Tablo 5'e göre olumsuz değerlendirilme korkusu ve akademik başarı değişkeni arasındaki standartlaştırılmış yol katsayısı $\beta=-0.476(p<.05)$ olarak bulunmuştur. Buna göre grupiçi düzeyde öğrencilerin akademik başarıları üzerinde olumsuz değerlendirilme korkusunun doğrudan etkisi orta düzeydedir. Olumsuz değerlendirilme korkusundaki bir birimlik artış akademik başarıda $-0.47^{\prime}$ 'lik bir azalmaya neden olmaktadır. Abuelfadl (2015) yaptığı çalışmada öğrencilerin akademik başarıları ile olumsuz değerlendirilme korkuları arasında negatif yönde düşük düzeyde bir ilişki olduğu sonucuna ulaşmıştır. Araştırma sonucuna göre akademik başarıdaki değişimin \% 37'si olumsuz değerlendirilme korkusundan kaynaklanmaktadır. Yine benzer şekilde Dordinejad ve Ahmadabad (2014) ve Horwitz'in (2001) yaptıkları çalışmalarda da olumsuz değerlendirilme korkusu ve akademik başarı arasında negatif yönde orta düzeyde bir ilişki bulunmuştur.

Akademik risk alma davranışı ile akademik başarı değişkeni arasındaki standartlaştırılmış yol katsayısı $\beta=0.416(\mathrm{p}<.05)$ olarak bulunmuştur. Buna göre grupiçi düzeyde öğrencilerin akademik başarılarında, akademik risk alma davranışının doğrudan etkisi orta düzeydedir. Akademik risk alma davranışındaki bir birimlik artış akademik başarıda 0.41 'lik bir artışa neden olmaktadır. Araştırmanın bu bulgusu da alanyazında yer alan çalışmalarla benzerlik göstermektedir. Çakır ve Yaman'ın (2015) ortaokul öğrencilerinin zihinsel risk alma davranışları ile başarıları arasındaki ilişkiyi belirlemek için yaptıkları çalışmada söz konusu iki değişken $(r=$ $.357 ; \mathrm{p}<.05$ ) arasında da orta düzeyde pozitif yönde manidar bir ilişkinin olduğu sonucuna ulaşı1mıştır. Henriksen ve Mishra (2013) eğitim ortamlarının düzenlemelerle iyileştirilerek öğrencilerin akademik risk alma düzeylerinin yükseltilmesi ile öğrenci başarısının da pozitif yönde gelişme göstereceğini belirtmektedir.

Sosyoekonomik düzey, olumsuz değerlendirilme korkusu ve akademik risk alma davranışı değişkenleri birlikte akademik başarıdaki değişkenliğin \% 89.9'unu açıklamaktadır $\left(\mathrm{R}^{2}=.899\right)$. Gruplararası düzeyde (okul) sınıf öğrenci sayısı ile akademik başarı arasındaki standartlaştırılmış yol katsayısı $\mathrm{y}=-0.439(\mathrm{p}<.05)$, öğretmen başına düşen öğrenci sayısı ile akademik başarı arasındaki standartlaştırılmış yol katsayısı y $=0.348(\mathrm{p}<.05)$ olarak bulunmuştur. Gruplararası düzeyde ise okulların akademik başarıları üzerindeki sınıf öğrenci sayısı ve öğretmen başına düşen öğrenci sayısının doğrudan etkileri orta düzeydedir. Okul düzeyinde ele alınan değişkenler arasında en güçlü etkiyi sınıf öğrenci sayısı göstermektedir. Sınıf öğrenci sayısı ve öğretmen başına düşen öğrenci sayısı birlikte okulların akademik başarılarındaki değişkenliğin \% 39.9'unu açıklamaktadır $\left(\mathrm{R}^{2}=.399\right)$.

Sosyoekonomik düzey, olumsuz değerlendirilme korkusunda meydana gelen değişikliğin \% 53.8'inin açıklamaktadır $\left(\mathrm{R}^{2}=.538\right)$. Sosyoekonomik düzey olumsuz değerlendirilme korkusu üzerinde doğrudan, negatif yönde ve güçlü bir etkiye sahiptir 
$(\beta=-0.734 ; p<.05)$. Bir başka deyişle, sosyoekonomik düzeyde meydana gelen bir birimlik artış, olumsuz değerlendirilme korkusunda $0.73^{\prime} l u ̈ k$ bir azalmaya neden olmaktadır. Akademik risk alma davranışında meydana gelen değişkenliğin \% 68.9'u, sosyoekonomik düzey değişseni tarafından açıklanmaktadır $\left(\mathrm{R}^{2}=.689\right)$. Sosyoekonomik düzey akademik risk alma davranışı üzerinde doğrudan, pozitif yönde ve güçlü bir etkiye sahiptir $(\beta=0.830 ; p<.05)$. Olumsuz değerlendirilme korkusu ile sosyoekonomik düzey arasındaki ilişkiyi inceleyen araştırmaların (Amies, Gelder ve Shaw, 1983; Güz ve Dilbaz, 2003; Solyom ve Solyom, 1986) sonuçlarına göre, eğitim ve gelir düzeyi yüksek ailelerin çocuklarında olumsuz değerlendirilme korkusunun görülme sıklığı daha azdır. Ebeveynlerinin düşük eğitim ve gelir düzeylerine sahip olması sosyal kaygıya neden olabilmektedir (Demir, Karaçetin, Eralp-Demir ve Uysal, 2013; Erkan, 2002).

Grupiçi düzeydeki modelde yer alan olumsuz değerlendirilme korkusu ve akademik risk alma değişkenlerinin aracılık etkisi incelenmiştir. Tablo 6'da bağımsız değişkenlerin bağımlı değişkenler üzerindeki dolaylı ve toplam etkileri görülmektedir.

Tablo 6

Grupiçi Düzeyde (Öğrenci) Doğrulanan Modeldeki Dolaylı ve Toplam Etkiler

\begin{tabular}{llllll}
\hline & $\boldsymbol{\beta}$ & St. Hata & t & p & $\boldsymbol{\beta}$ STDYX \\
\hline Grupiçi Düzey Dolaylı Etki & & & & & \\
SED $\rightarrow$ ODK $\rightarrow$ BAŞARI & 5.513 & 0.251 & 22.006 & 0.000 & 0.349 \\
SED $\rightarrow$ ARA $\rightarrow$ BAŞARI & 5.453 & 0.471 & 11.589 & 0.000 & 0.346 \\
\hline Toplam Etki & 13.061 & 0.488 & 26.786 & 0.000 & 0.828 \\
\hline
\end{tabular}

Tablo 6 incelendiğinde, sosyoekonomik düzey değişkeninin akademik başarıyı yordamasında, olumsuz değerlendirme korkusu ve akademik risk alma aracı değişkenlerinin manidar bir etkisi vardır. Sosyoekonomik düzey değişkeninin, olumsuz değerlendirilme korkusu aracılığıyla akademik başarı puanlarına 0.349 kadar, akademik risk alma aracılığıyla akademik başarı puanlarına 0.346 kadar dolaylı etkisinin olduğu görülmektedir $(\mathrm{p}<.05)$. Sosyoekonomik düzey gizil değişkeninin grupiçi düzeyde akademik başarıya olan toplam etkisi $0.828^{\prime}$ 'dir. $\mathrm{Bu}$ durum öğrencilerin sosyoekonomik düzeylerindeki artışın akademik başarıyı doğrudan pozitif yönde etkileyebileceği gibi, olumsuz değerlendirilme korkusu ve akademik risk alma davranışlarını da etkileyerek bu değişkenler üzerinden de akademik başarıya etki ettiği şeklinde yorumlanabilir.

Tablo 6 incelendiğinde, gruplararası düzeyde sınıf öğrenci sayısı ve öğretmen başına düşen öğrenci sayısı değişkenlerinin, akademik başarı değişkenine doğrudan etkilerinin negatif yönde olduğu görülmektedir. Gruplararası düzeyde (okul) sınıf öğrenci sayısı ile akademik başarı değişkeni arasındaki standartlaştırılmış yol katsayısı $\beta=-0.439(p<.05)$ olarak bulunmuştur. Buna göre gruplararası düzeyde öğrencilerin akademik başarıları üzerinde sınıf öğrenci sayısınun doğrudan etkisi orta 
düzeydedir. Sınıf öğrenci sayısındaki bir birimlik artış okulların başarısında 0.44'lük bir azalmaya neden olmaktadır. Araştırmanın bu bulgusu da yine alanyazındaki çalışmaların bulgularını destekler niteliktedir. Acar (2013) yaptığı bir çalışmada sınıf öğrenci sayısı fazla olan okulların başarılarının daha düşük olduğu sonucuna ulaşmıştır. Benzer şekilde, sınıf öğrenci sayısı arttıkça akademik başarının düştüğü sonucuna ulaşan başka çalışmalar da bulunmaktadır (Akyüz 2006; Boozer ve Rouse, 2001; Çelebi 2010).

Tablo 6'da gruplararası düzeyde akademik başarıyla doğrudan ilişkisi olan bir başka değişken ise öğretmen başına düşen öğrenci sayısıdır. Gruplararası düzeyde (okul) öğretmen başına düşen öğrenci sayısı ile akademik başarı değişkeni arasındaki standartlaştırılmış yol katsayısı $\beta=-0.348(\mathrm{p}<0.05)$ olarak bulunmuştur. Buna göre gruplararası düzeyde öğrencilerin akademik başarıları üzerinde öğretmen başına düşen öğrenci sayısı değişkeninin doğrudan etkisi orta düzeydedir. Öğretmen başına düşen öğrenci sayısındaki bir birimlik artış okulların başarısında 0.34'lük bir azalmaya neden olmaktadır. Araştırmanın bu bulgusunu da destekleyen çalışmalar bulunmaktadır. Yıldırım’ın (2012) yaptığı çalışmada öğretmen/öğrenci oranı ile okuduğunu anlama başarısı arasında negatif yönde anlamlı bir ilişki olduğu belirlenmiştir. Öğretmen başına düşen öğrenci sayısı değişkenindeki bir birimlik artış, okuduğunu anlama başarısını 0.251 'lik bir düşüşe yol açmaktadır.

\section{Tartışma, Sonuç ve Öneriler}

Öğrencilerin akademik başarıları, okullar arasında manidar bir farklılık göstermektedir. Akademik başarının okullar arasında değişkenliğini gösteren sınıfiçi korelasyon katsayısı .29 olarak hesaplanmıştır. Buna göre öğrencilerin akademik başarılarındaki farklılıkların \% 29'u okullar arası farklılıklardan, \% 71'i ise aynı okulda öğrenim gören öğrenciler arasındaki farklılıktan kaynaklandığı sonucuna ulaşılmıştır. Grupiçi ve gruplararası düzeyi içeren çok düzeyli yapısal eşitlik modeli analizleri sonucunda, araştırmacı tarafından oluşturulan kuramsal modelin elde edilen veriler üzerinden doğrulandığı, model veri uyum indekslerinin iyi düzeyde olduğu sonucuna ulaşılmıştır. Doğrulanan model üzerinde yer alan değişkenlerin doğrudan ve dolaylı etkileri incelenmiştir.

Grupiçi düzeyde sosyoekonomik düzey, olumsuz değerlendirilme korkusu ve akademik risk alma davranışı değişkenlerinin akademik başarıya olan doğrudan etkileri manidar bulunmuştur. Sosyoekonomik düzey ve akademik risk alma davranışı değişkenlerinin akademik başarı üzerindeki etkisi pozitif yönde iken, olumsuz değerlendirilme korkusu değişkeninin akademik başarı üzerindeki etkisi negatif yöndedir. Sosyoekonomik düzey değişkeni akademik başarıyı doğrudan etkilediği gibi olumsuz değerlendirilme korkusu ve akademik risk alma davranışı aracılığıyla da etkilemektedir. Sosyoekonomik düzey değişkeninin olumsuz değerlendirilme korkusu üzerindeki etkisi negatif yöndedir. Öğrencilerin sosyoekonomik düzeyleri arttıkça olumsuz değerlendirilme korkuları azalmaktadır. Sosyoekonomik düzey değişkeninin akademik risk alma davranışı üzerindeki etkisi pozitif yöndedir. Gruplararası düzeyde sınıf öğrenci sayısı ve öğretmen başına düşen öğrenci sayısı 
değişkenlerinin akademik başarıya olan doğrudan etkileri manidardır. Her iki değişkeninin akademik başarı üzerindeki etkisi negatif yöndedir. Sınıf öğrenci sayısı ve öğretmen başına düşen öğrenci sayısı arttıkça akademik başarı puanları düşmektedir.

Ailelerin sosyoekonomik düzeylerinin öğrenci başarısında özellikle okul düzeyinde önemli bir yeri vardır. Araştırma sonuçlarına göre sosyoekonomik düzeyi yüksek öğrenci nüfusuna sahip okullardaki öğrencilerin başarısı da yüksektir. Anne ve babanın eğitim ve geliri yükseldikçe öğrencilerin başarılarının da arttı̆̆ görülmektedir. Daha düşük sosyoekonomik düzeye sahip öğrenciler sosyoekonomik olarak daha üst ailede yetişmiş çocuklar ile eşit eğitim haklarına sahip olamamakta bu durum da öğrenmeyi olumsuz etkilemektedir. Bu nedenle eğitimle ilgilenen devlet kurumlarının sosyoekonomik düzeye dayalı farklılıkları ortadan kaldıracak politikalar üretmesi, eğitimde fırsat eşitliğinin sağlanması önerilmektedir. Ebeveynlerden herhangi birinin eğitim düzeyi yükseldikçe çocuklarına sağlayacakları akademik destek de artacaktır. Bu nedenle, okullardaki eğitim ortamlarının düşük eğitim düzeyine sahip ebeveynlere ve çocuklarına akademik olarak katkı sağlayacak, yönlendirecek şekilde düzenlenmesi öğrencilerin performanslarının gelişimine katkı sağlayabilir. Düşük sosyoekonomik düzeye sahip ailelerin çocuklarına yatırım yapmak, toplumsal gelişim açısından faydalı olabilecektir.

Araştırmada olumsuz değerlendirilme korkusunun akademik başarıyı manidar olarak yordadığı bulunmuştur. Öğrencilerin olumsuz değerlendirilme korkuları arttıkça akademik başarıları düşmektedir. Öğrencilerin öğrenmeleri üzerinde etkili olan duyuşsal özelliklerden biri olumsuz değerlendirilme korkusudur. Olumsuz değerlendirilme korkusunun ergenlik döneminde olan öğrenciler üzerindeki etkisi düşünüldüğ̈̈nde, öğretmenlerin ve ebeveynleri öğrencilere arkadaşlarının yanında özgüvenini, öz yeterlik algısını zedeleyici eleştirilerde bulunmaktan kaçınmalarının yararlı olacağı düşünülmektedir. Okul rehberlik birimlerince ailelerin çocukları ile ilgili gerçekçi beklentiler içerisine girmesi, öğrencilerin kendilerini daha iyi tanımalarını sağlamak amacıyla hem öğrenci ve ailelere seminerler verilebilir. Ayrıca okul rehberlik birimleri öğrencilerin sosyal kaygı ve olumsuz değerlendirilme korkularını belirleyebilmek için envanterler, olumsuz duygu ve düşüncelerle baş edebilmeleri için işlevsel olmayan düşünceleri yeniden yapılandırma çalışmaları yapabilirler. Okullarda öğrencilerin sosyal ortamlarda kendilerini daha rahat ifade etmeleri, olumlu duygu ve düşüncelere sahip olmaları için atılganlık eğitimi verilebilir.

Araştırma sonucuna göre akademik risk alma davranışının öğrenci başarısını olumlu yönde etkilediği görülmektedir. Öğrenci başarısı üzerinde olumlu bir etkiye sahip olan akademik risk alma davranışının güçlendirilmesi, öğretmenlerin derslerde öğrencilere risk alınabilecekleri problem durumları ya da etkinlikler oluşturmasının yararlı olacağı söylenebilir. Sınıf ortamında her bir öğrenciye eşit söz hakkı verilmesine özen göstermesi, söz hakkı alan öğrencilere olumlu dönütler vermesi risk alma davranışının gelişmesine katkı sağlayabilir. 
Sınıf mevcutlarının azaltılması sınıf yönetimi ve öğrenme ortamının daha etkili olması açısından yararlı olacaktır. Sınıf mevcutları kalabalık olan bölgelerde yeni okullar ya da varolan okullara ek binalar yapılarak yeni sınıfların açılması önerilebilir. Özellikle kalabalık sınıfların olduğu okullarda görev yapan öğretmenlere, sınıf yönetimi ve öğretim yöntem ve teknikleri eğitimleri verilebilir. Sınıf mevcutlarının azaltılması öğretmen başına düşen öğrenci sayısının da azalmasını sağlayacak böylece öğretmenler öğrenciler ile daha nitelikli zaman geçirebilecek, daha çok ilgilenebilecektir, gelişimlerine daha çok katkı sağlayabilecektir.

Okulların sosyoekonomik düzeyi okulların başarısı üzerinde etkilidir. Sosyoekonomik düzeyi düşük ailelerin yaşadıkları bölgelerdeki okulların sınıf mevcutları ve öğretmen başına düşen öğrenci sayıları da artmaktadır. Bu nedenle sosyoekonomik düzeyi düşük ailelerin çocuklarının öğrenim gördüğü okulların eğitim ve öğretim alt yapısı, görece daha yüksek sosyoekonomik düzeye sahip çocukların gittiği okullarla benzer duruma getirilmesi, bakanlıklarca bu okulların desteklenmesi, eğitim öğretim ortam ve kaynaklarının geliştirilmesi okulların akademik olarak geliştirilmesi açısından önemli olabilir.

\section{Kaynakça}

Abuelfadl, M. A. (2015). Anxiety as a predictor of academic achievement of students with learning difficulties. International Journal of Psychology and Behavioral Sciences, 5(4), 169-177.

Acar, M. (2013). Öğrenci başarllarının belirlenmesi sınavında türkçe dersi başarısının ögrenci ve okul özellikleri ile ilişkisinin sıradizinsel lineer model ile analizi (Yayımlanmamış doktora tezi, Ankara Üniversitesi, Eğitim Bilimleri Enstitüsü, Ankara, Türkiye). https://tez.yok.gov.tr/UlusalTezMerkezi/'nden elde edilmiştir. (Tez No. 342470)

Akbaba, S. (2006). Eğitimde motivasyon. Kazım Karabekir Eğitim Fakültesi Dergisi, $13,343-361$.

Akkalkan, H. (2009). Ankara ili Çankaya ilçesinde okul büyüklüğ̈̈nün öğrencilerin akademik başarısı, okula devamı ve disiplini ile ilişkisi. (Yayımlanmamış yüksek lisans tezi, Ankara Üniversitesi, Eğitim Bilimleri Enstitüsü, Ankara, Türkiye). https://tez.yok.gov.tr/UlusalTezMerkezi/'nden edinilmiştir. (Tez No. 324821)

Akyüz, G. (2006). Türkiye'de ve Avrupa birliği ülkelerinde öğretmen ve sınıf niteliklerinin matematik başarısına etkisinin incelenmesi. Ilköğretim Online, 5(2), 75-86. 
Alivernini, F., and Manganelli, S. (2015). A multilevel structural equation model testing the influences of socioeconomic status and pre-primary education on reading literacy in Italy. Procdeia-Social and Behavioral Sciences. 205, 168172.

Alkan, V. (2015). Akademik ortamlarda olumsuz değerlendirilme korkusu ölçeğinin geliş̧tirilmesi. (Yayımlanmamış yüksek lisans tezi, Ankara Üniversitesi, Eğitim Bilimleri Enstitüsü, $\quad$ Ankara, https://tez.yok.gov.tr/UlusalTezMerkezi/'nden edinilmiştir. (Tez No. 396164)

Amies, P. L., Gelder, M. G., and Shaw, P. M. (1983). Social fobia: A comparative clinical study. British Journal of Psychiatry, 142, 174-179.

Anıl, D. (2009). Uluslararası öğrenci başarılarını değerlendirme programı (PISA)'nda Türkiye'deki öğrencilerin fen bilimleri başarılarını etkileyen faktörler. Eğitim ve Bilim Dergisi, 34(152), 87-100.

Bauer, D. J. (2003). Estimating multilevel linear models as structural equation models. Journal of Educational and Behavioral Statistics, 28, 135-167.

Bentler, P. M., and Liang, J. (2003). Two-level mean and covariance structures: Maximum likelihood via and em algorithm. S. P. Reise and N. Duan (Eds.), in Multilevel modeling: Methodological advances, issues, and applications (pp. 53-70). Hillsdale, New Jersey, NJ: Erlbaum.

Berberoğlu, G., Çelebi Ö., Özdemir, E., Uysal, E. ve Yayan, B. (2003). Üçüncü uluslararası matematik ve fen çalışmasında Türk öğrencilerin başarı düzeylerini etkileyen etmenler. Eğitim Bilimleri ve Uygulama, 2(3), 3-14.

Boozer, M., and Rouse, C. (2001). Intraschool variation in class size: Patterns and implications. Journal of Urban Economics, 50(1), 163-189.

Boyer, T. W. (2006). The development of risk-taking: A multi-perspective review. Developmental Review, 26(3), 291-345.

Boztaş, M. H. ve Sungur, M. Z. (2001). Kaçıngan kişilik bozukluğu. Psikiyatri Dünyast, 5, 71-79.

Boztunç, N. (2010). Uluslararası öğrenci değerlendirme programı'na (PISA) katılan Türk ögrencilerin 2003 ve 2006 yıllarındaki matematik ve fen bilimleri başarılarının incelenmesi (Yayımlanmamış yüksek lisans tezi, Hacettepe Üniversitesi, Sosyal Bilimler Enstitüsü, Ankara, Türkiye). https://tez.yok.gov.tr/UlusalTezMerkezi/'nden edinilmiştir. (Tez No. 265304)

Can, S. (2012). Çoklu bağlantısallığın çok düzeyli yapısal eşitlik modellemesi üzerindeki etkisi. (Yayımlanmamış doktora tezi, Ege Üniversitesi, Sosyal Bilimler Enstitüsü, https://tez.yok.gov.tr/UlusalTezMerkezi/'nden edinilmiştir. (Tez No. 314188) 
Chiu, M. M. (2007). Families, economies, cultures, and science achievement in 41 countries: Country-school and student-level analyses. Journal Of Family Psychology, 21(3), 510-519.

Clifford, M. M. (1991). Risk taking, theoretical, empirical, and educational considerations. Educational Psychologist, 26(3 and 4), 263-297.

Cohen, J. (1992). A power primer. Psychological Bulletin, 112, 155-159.

Creswell, J. W. (2008). Educational research: Planning, conducting, and evaluating quantitative and qualitative research. Upper Saddle River, New Jersey, NJ: Pearson/Merrill Education.

Çakır, E. ve Yaman, S. (2015). Ortaokul öğrencilerinin zihinsel risk alma becerileri ve üst bilişsel farkındalıkları ile akademik başarıları arasındaki ilişsi. Gazi Ĕ̈itim Bilimleri Dergisi. 1(2), 163-178.

Çelebi, Ö. (2010). PISA 2006 uluslararası ögrenci değerlendirme programında insan kaynakları ve fiziksel kaynakların ögrencilerin fen okuryazarlığına olan etkisinin kültürlerarası karşılaştırılması. (Yayımlanmamış doktora tezi, Orta Doğu Teknik Üniversitesi, Fen Bilimleri Enstitüsü Ankara, Türkiye). https://tez.yok.gov.tr/UlusalTezMerkezi/'nden edinilmiştir. (Tez No. 285726)

Çetin, B., İlhan, M. ve Yılmaz, F. (2014). Olumsuz değerlendirilme korkusu ve akademik risk alma arasındaki ilişkinin kanonik korelasyonla incelenmesi. Kuram Ve Uygulamada Eğitim Bilimleri, 14(1), 135-158.

Çiftçi, S. (2006). Sosyal bilgiler öğretiminde proje tabanlı ögrrenmenin ögrencilerin akademik risk alma düzeylerine, problem çözme becerilerine, erişilerine kalıcılığa ve tutumlarına etkisi. (Yayımlanmamış doktora tezi, Selçuk Üniversitesi, Sosyal Bilimler Enstitüsü, Konya, Türkiye). https://tez.yok.gov.tr/UlusalTezMerkezi/'nden edinilmiştir. (Tez No. 189321)

Demir, İ. ve Kılıç, S. (2010). Öğrencilerin matematik başarısına etkileyen faktörlerin PISA 2003 kullanılarak incelenmesi. Hacettepe Üniversitesi Ĕ̈itim Fakültesi Dergisi, 38, 44-54.

Demir, T., Karaçetin, G., Eralp-Demir, D., and Uysal, O. (2013). Prevalence and some psychosocial characteristics of social anxiety disorder in an urban population of Turkish children and adolescents. European Psychiatry, 28(1), 64-69.

Denrell, J. (2007). Adaptive learning and risk taking, Psychlogical Review, 114(1), 177-187.

Dordinejad, F. G., and Ahmadabad, R. M. (2014). Examination of the relationship between foreign language classroom anxiety and English achievement among male and female Iranian high school students. International Journal of Language Learning and Applied Linguistics World, 6(4), 446-460. 
Durmuş, E. (2008). Yaratıcı drama ile bütünleştirilmiş grupla psikolojik danışmanın üniversite öğrencilerinin utangaçlık düzeylerine etkisi. Ankara Üniversitesi Eğitim Bilimleri Dergisi, 41(1), 93-114.

Dünya Bankası (2013). Promoting excellence in Turkey's schools. World Bank. Retrieved from http://www.worldbank.org/tr.

Ellez, A. M., Gümüş, N. ve Seferov, R. (2009). Coğrafya bölümü öğrencilerinin istatistik dersine yönelik tutumları: Türkiye ve Azerbaycan örneği. Selçuk Üniversitesi Sosyal Bilimler Enstitüsü Dergisi, 21, 187-194.

Erden, M. ve Akman, Y. (2011). Gelişim ve öğrenme. Ankara: Arkadaş Yayınevi.

Ergün, M. (1992). Eğitim ve toplum-Eğitim sosyolojisine giriş. Ankara: Ocak Yayınları.

Erkan, Z. (2002). Ergenlerin sosyal kaygı düzeyleri, ana-baba tutumları ve ailede görülen risk faktörleri üzerinde bir çalı̧̧ma (Yayımlanmamış doktora tezi, Çukurova Üniversitesi, Sosyal Bilimler Enstitüsü, Adana, Türkiye). https://tez.yok.gov.tr/UlusalTezMerkezi/'nden edinilmiştir. (Tez No. 125289)

Feldman, J.M. (2003). The relationship among college freshmen's cognitive risk tolerance, academic hardiness, and emotional intelligence and their usefulness in predicting academic outcomes (Unpublished $\mathrm{Ph}$ dissertation). Temple University, Philadelphia, Pennsylvania, PA. Retrieved from https://www.researchgate.net/publication/35222264

Gömleksiz, M. N. (2003). İngilizce duyuşsal alana ilişkin bir tutum ölçeğinin geçerlik ve güvenirliği. Firat Üniversitesi Sosyal Bilimler Dergisi, 13(1), 215-226.

Gömleksiz, M. N. ve Yüksel, Y. (2003). İlköğretim 4. ve 5. sınıf öğrencilerinin fen bilgisi dersine ilişkin kaygıları. Doğu Anadolu Bölgesi Araştırmaları, 3, 71-81.

Gregg, P., and Machin, S. (1998). Child development and success or failure in the youth labour market (397. July, 1998). Retrieved from http://cep.lse.ac.uk/pubs/download/DP0397.pdf

Güz, H. ve Dilbaz, N. (2003). Sosyal kaygı bozukluğunda cinsiyet farklılıkları. Klinik Psikiyatri Dergisi ,6(1), 32-38.

Halstead, J. M., and Taylor, M. J. (1996). Values in education and education in values. London: The Falmer Press. Retrieved from https://eric.ed.gov/?id=ED393218

Hazır-Bıkmaz, F. (2001). Illköğretim 4. ve 5. sinıf öğrencilerinin fen bilgisi dersindeki başarılarını etkileyen faktörler. (Yayımlanmamış yüksek lisans tezi, Ankara Üniversitesi, Sosyal Bilimler Enstitüsü, Ankara, Türkiye). https://tez.yok.gov.tr/UlusalTezMerkezi/'nden edinilmiştir. (Tez No. 99935)

Heck, R. H. (2001). Multilevel modeling with sem. J. A. Marcoulides and R. E. Schumacker (Eds.), New developmentsm and techniques in structural equation 
modeling (pp. 89-127). Mahwah, New Jersey, NJ: Lawrence Erlbaum Associates.

Heck, R. H., and Thomas, S. L. (2015). An introduction to multilevel modeling techniques (Third edition). New York, NY: Routledge.

Hemmings, B., Grootenboer, P., and Kay, R. (2011). Predicting mathematics achievement: The influence of prior achievement and attitudes. International Journal of Science And Mathematics Education, 9(3), 691-705.

Henriksen, D., and Mishra, P. (2013). Learning from creative teachers. Educational Leadership, 70(5), 15-19.

Horwitz, E. (2001). Language anxiety and achievement. Annual Review of Applied Linguistics, 21, 112-126.

House, D. J. (2002). An investigation of the effects of gender and academic selfefficacy on academic risktaking for adolescent students (Doctoral dissertation). Retrieved from https://shareok.org/bitstream/handle/11244/46831/Thesis2002D-H842i.pdf?sequence $=1 \&$ is Allowed $=y$

Hox, J. J. (2010). Multilevel analysis: Techniques and applications (Second edition). New York, NY: Routledge.

Kalaycı, Ş. (2006). SPSS uygulamalı çok değişkenli istatistik teknikleri. Ankara: Asil Yayın Dağıtım.

Kalemoğlu-Varol, Y. ve İmamoğlu, A. F. (2014). Türk ve İngiliz eğitim sistemlerine ilişkin sayısal verilerin karşılaştırılmalı olarak incelenmesi. Ĕgitim ve Öğretim Araştırmaları Dergisi 3(1), 406-418.

Kaplan, D., and Elliot, P. R. (1997). A didactic example of multilevel structural equation modeling applicable to the study of organizations. structural equation modeling. A Multidiscipliuary Journal, 4, 1-24.

Karabay, E. (2012). Sosyo-kültürel değişkenlerin PISA fen okuryazarlı̆̆ını yordama gücünün yıllara göre incelenmesi. (Yayımlanmamış yüksek lisans tezi, Ankara Üniversitesi, Eğitim Bilimleri Enstitüsü, Ankara, Türkiye). https://tez.yok.gov.tr/UlusalTezMerkezi/'nden edinilmiştir. (Tez No. 311756)

Karabulut E. O. ve Bahadır Z. (2013). Ümit milli judo takımının olumsuz değerlendirilmekten korkma ve empatik eğilim düzeylerinin incelenmesi. Niğde Üniversitesi Beden Eğitimi ve Spor Bilimleri Dergisi 7(2), 108-115.

Karasakaloğlu N. ve Saracaloğlu A. S. (2009). Sınıf öğretmeni adaylarının Türkçe derslerine yönelik tutumları, akademik benlik tasarımları ile başarıları arasındaki ilişki. Yüzüncü Yll Üniversitesi Eğitim Fakültesi Dergisi, 4(1), 343-362.

Kline, R. B. (2005). Principles and practice of structural equation modeling (Second Edition). New York, NY: Guilford Publications, Inc. 
Korkmaz, H. (2002). Fen eğitiminde proje tabanl öğrenmenin yaratıcı düşünme, problem çözme ve akademik risk alma düzeylerine etkisi. (Yayımlanmamış doktora tezi, Hacettepe Üniversitesi, Sosyal Bilimler Enstitüsü, Ankara, Türkiye). https://tez.yok.gov.tr/UlusalTezMerkezi/'nden edinilmiştir. (Tez No. 113511)

Lemke, M., Calsyn, C., Lippman, L., Jocelyn, C., Kastberg, D., Liu, Y. Y., ... , and Bairu, G. (2002). Outcomes of learning: Results from the 2000 program for international student assessment of 15 -year-olds in reading, mathematics, and science literacy. Education Statistics Quarterly, 4(1), 59-67.

McNeal Jr., R. B., (1999). Parental involvement as social capital: Diverential evectiveness on science achievement, truancy, and dropping out. Social Forces $78,117-144$.

Muthén, L. and Muthén, B. (1998). Mplus user's guide (Sixth Edition). Los Angeles, California, CA: Muthén \& Muthén.

Noyan, F. (2009). Çok aşamalı yapısal eşitlik modellerinin iş tatmini ile örgütsel bağlllık arasındaki ilişki üzerine bir uygulama. (Yayımlanmamış doktora tezi, Marmara Üniversitesi, Sosyal Bilimler Enstitüsü, İstanbul, Türkiye). https://tez.yok.gov.tr/UlusalTezMerkezi/'nden edinilmiştir. (Tez No. 239956)

Organisation for Economic Co-operation and Development (2012). Equity and quality in education: Supporting disadvantaged students and schools. Paris: OECD Publishing.

Oral, I., ve Mcgivney, E. (2013). Türkiye'de matematik ve fen bilimleri alanlarında ögrenci performansı ve başarının belirleyicileri: TIMSS 2011 analizi. Retrieved from www.egitimreformugirisimi.org/wp-content/uploads/2017/03/ERGTIMSS-2011-Analiz-Raporu.pdf

Özer, Y. (2009). Uluslararası öğrenci değerlendirme programı (PISA) verilerine göre Türk ögrencilerin matematik ve fen bilimleri başarlları ile ilişkili faktörler. (Yayımlanmamış yüksek lisans tezi, Hacettepe Üniversitesi, Sosyal Bilimler Enstitüsü, Ankara, Türkiye). https://tez.yok.gov.tr/UlusalTezMerkezi/'nden edinilmiştir. (Tez No. 254782)

Özer, Y. ve Anıl, D. (2011). Öğrencilerin fen ve matematik başarılarını etkileyen faktörlerin yapısal eşitlik modeli ile incelenmesi. Hacettepe Üniversitesi Ĕgitim Fakültesi Dergisi, 41, 313-324.

Özkan, H. H. (2005). Öğrenme öğretme modelleri açısından modüler öğretim. Atatürk Üniversitesi Sosyal Bilimler Enstitüsü Dergisi, 6(2), 117-128.

Polat, G. (2008). Sosyo-ekonomik değişkenlerin yükseköğretim öğrencilerinin akademik başarısı üzerindeki etkisi. (Yayımlanmamış yüksek lisans tezi, Süleyman Demirel Üniversitesi, Sosyal Bilimler Enstitüsü, Isparta, Türkiye). https://tez.yok.gov.tr/UlusalTezMerkezi/'nden edinilmiştir. (Tez No. 226456) 
Raudenbush, S. W., and Bryk, A. S. (2002). Hierarchical linear models: Applications And Data Analysis Methods. Thousand Oaks, California, CA: Sage Publications, Inc.

Senemoğlu, N. (2009). Gelişim ögrenme ve ögretim kuramdan uygulamaya. Ankara: PegemA Akademi.

Solyom, I. L., and B. Solyom, C. (1986) Delineating social phobia. British Journal of Psychiatry, (149), 461-470.

Stapleton, L. M. (2006). Using multilevel structural equation modeling techniques with complex sample data. G. R. Hancock and R. O. Mueller (Eds.), in Structural equation modeling. A second course (pp. 343-383). Greenwich, Connecticut: Information Age Publishing.

Sun, L., and Bradley, K. D. (2011). A multi-level model approach to investigating factors impacting science achievement for secondary school students-PISA Hong Kong sample. International Journal of Science Education, 34, 2107-2125.

Şimşek, G. G., and Noyan, F. (2009). The effect of perceived instructional effectiveness on student loyalty: A multilevel structural equation model. Hacettepe Üniversitesi Eğitim Fakültesi Dergisi, 36, 109-118.

Thompson B. (2000). Ten commandments of structural equation modeling. Grimm LG, Yarnold PR. (Ed.), in Reading and understanding more multivariate statistics (pp. 261-283). Washington, WA: American Psychological Association.

Tok, Ş. (2008). Fen bilgisi dersinde yansıtıcı düşünme etkinliklerinin öğrencilerin akademik başarılarına ve fen bilgisi dersine yönelik tutumlarına etkisi. Ilköğretim Online, 7(3), 557-568.

Usta, G. H. (2014). PISA 2003 ve PISA 2012 matematik okuryazarllğg üzerine uluslararası bir karşılaştırma: Türkiye ve Finlandiya. (Yayımlanmamıș doktora tezi, Ankara Üniversitesi, Eğitim Bilimleri Enstitüsü, Ankara, Türkiye). https://tez.yok.gov.tr/UlusalTezMerkezi/'nden edinilmiştir. (Tez No. 370331)

Wigfield, A., and Wentzel, K. (2007). Introduction to motivation at school: Interventions that work. Educational Psychologist, 42, 191-196.

Yıldırım, Ö. (2012). Okuduğunu anlama başarısıyla ilişkili faktörlerin aşamalı doğrusal modellemeyle belirlenmesi: PISA 2009 Hollanda, Kore Ve Türkiye karşılaştırması. (Yayımlanmamış doktora tezi, Ankara Üniversitesi, Eğitim Bilimleri Enstitüsü, Ankara, Türkiye). https://tez.yok.gov.tr/UlusalTezMerkezi/'nden edinilmiştir. (Tez No. 311754)

Yokuş, T. (2013). The relationship between the state-trait anxiety levels and academic achievement of music teacher candidates. International Online Journal of Primary Education, 2(1), 25-31. 


\title{
Investigation of Relation Between Academic Achievement And School, Family And Student's Characteristics With Multilevel Structural Equation Modelling $^{1}$
}

\begin{tabular}{cccc}
\hline ARTICLE TYPE & Received Date & Accepted Date & Published Date \\
Research Article & 02.11 .2019 & 06.21 .2019 & 10.04 .2019 \\
\hline
\end{tabular}

Gülçin Uzun

Bilnet Schools

Ömay Çokluk Bökeoğlu

Ankara University

\begin{abstract}
The aim of this research is to investigate the relationship between the academic achievement of students attending secondary school of grades 6,7 and 8 and school, family and student characteristics with multilevel structure equation modelling. The sample of this research using the predictive correlational research design is composed of 6,7 and 8 grades of students who are studying in a total of thirty five schools including five official and two private schools selected from each of the provinces of Ankara which are Çankaya, Keçiören, Mamak, Altındağ and Yenimahalle in the first term of the academic year of 2016-2017. In this research to collect data, the student information questionnaire developed by the researcher, the scale of fear of negative evaluation in the academic environment developed by Alkan (2015) and the academic risk taking scale adapted to Turkish by Korkmaz (2002) were used. As a result of the research, at the within level the direct effects of the socioeconomic level, the fear of negative evaluation and academic risk taking behavior variables were found to be significant on academic achievement. While the effects of socioeconomic level and academic risk-taking behavior variables on academic achievement is positive, the effect of fear of negative evaluation variable on academic achievement is negative. In between level, the direct effects of the classroom size and number of students per teacher have significant direct effect on academic achievement. The effect of both variables on academic achievement is negative.
\end{abstract}

Keywords: Academic achievement, multilevel structural equation model, fear of negative evaulation, academic risk taking, mediation.

${ }^{1}$ This study was produced from the doctoral thesis of the first author which was completed under the consultancy of the professor Ömay Çoklu Bökeoğlu.

${ }^{2}$ Corresponding Author: Ph. D., E-mail: cirakgulcin@gmail.com, https://orcid.org/0000-0003-4897-6507 ${ }^{3}$ Prof. Ph. D., Faculty of Educational Sciences, Department of Measurument and Evaluation, E-mail: cokluk@education.ankara.edu.tr, https://orcid.org/0000-0002-3879-9204 


\section{Purpose and Significance}

Countries aim to educate qualified students through education. In order to achieve this goal, it is necessary to develop the skills of the students and to identify the factors that affect the development; because the academic achievement of the students is considered as an indicator of the effectiveness of the education system. In developing countries such as Turkey socio-economic status and its effect on academic achievement shaped by family background, depending on factors such as education level, it attracts more attention with each passing day it becomes undeniable (OECD, 2012; Oral and McGivney, 2013; World Bank, 2013). In the countries that rank lower in the International Student Assessment Program (PISA), the student's academic success is closely related to the socioeconomic status of her family (OECD, 2012).

When the results of the researches related to the student achievement in general are evaluated, it can be seen that the factors affecting the success are inseparable and intertwined structures. Students are clustered in classrooms, classes in schools, schools in cities, cities in regions and regions in countries. These data obtained from education-related researches are hierarchical (Noyan, 2009). Because of the interdependence of observations in the hierarchical data set, the use of single-level analysis methods leads to statistical and conceptual problems (Hox, 2010). In the analysis of data in the hierarchical structure, three different methods are used: aggregation, disaggregation and multilevel models (Stapleton, 2006). As the number of data will be as much as the number of groups, the intergroup exchange is investigated in the aggregate approach that is ignored by the individual level and analyzed over the group (Can, 2012). Multilevel models ensure that the relationships between variables at each level of hierarchical data are handled simultaneously. Thus, it eliminates the statistical and conceptual problems encountered when analyzing only the individual or only group level (Heck, 2001).

As a result of the literature review, it is observed that studies using hierarchical data related to student achievement in the field of education become widespread and hierarchical linear models, which are a type of multi-level models in general, are used (Akyüz, 2006; Demir and Kılıç, 2010; Şimşek and Noyan, 2009; Usta, 2014; Yıldırım, 2012). However, these models have the disadvantages of inclusion of implicit variables in the model and their inability to provide complex path analysis (Bauer, 2003). In addition to direct effects as well as the indirect effects of the relationship between the variables are examined, it is important to understand the reasons for the relationship between variables. This limitation of the hierarchical linear models makes it important to examine the direct and indirect effects of school, family and student characteristics related to academic achievement both simultaneously with the group and at the intergroup level by using multilevel structural equation modeling. The aim of this research is to investigate the relationship between the academic achievement of students attending secondary school of grades 6,7 and 8 and school, family and student characteristics with multilevel structure equation modelling. 


\section{Method}

In this study, the relationship between academic achievement and family, student and school characteristics was investigated and the predictive correlational research design based on direct and indirect effects tests was used. The sample of this research using the predictive correlational research design is composed of 6,7 and 8 grades of students who are studying in a total of thirty five schools including five official and two private schools selected from each of the provinces of Ankara which are Çankaya, Keçiören, Mamak, Altındağ and Yenimahalle in the first term of the academic year of 2016-2017. In this research to collect data, the student information questionnaire developed by the researcher, the scale of fear of negative evaluation in the academic environment developed by Alkan (2015) and the academic risk taking scale adapted to Turkish by Korkmaz (2002) were used.

In the study, two different structural equation models with multi levels were set up. In these models in within level the socioeconomic level from family characteristics, the fear of negative evaluation and academic risk taking behaviors from the characteristics related to the students were used. In between level, the classroom size and the number of students per teacher were used. The relationship between socioeconomic level, fear of negative evaluation and academic risk taking behaviors, the classroom size and the number of students per teacher has been examined with a single level structural equation model as well.

\section{Results}

As a result of the research, at the within level the direct effects of the socioeconomic level, the fear of negative evaluation and academic risk taking behavior variables were found to be significant on academic achievement. While the effects of socioeconomic level and academic risk-taking behavior variables on academic achievement is positive, the effect of fear of negative evaluation variable on academic achievement is negative. The socioeconomic level directly affects the academic achievement as well as by mediation of the fear of negative evaluation and academic risk taking behavior. The effect of the socioeconomic level variable on the fear of negative evaluation is negative. In between level, the direct effects of the classroom size and number of students per teacher have significant direct effect on academic achievement. The effect of both variables on academic achievement is negative.

It has been concluded that the socioeconomic level variable in the research is directly related to the academic achievement at the between level. In addition, the direct effects of the fear of negative evaluation and academic risk taking behavior on academic achievement at the between level were significant. Both the within group and between level, all of the direct effects of independent variables to dependent variables are significant $(\mathrm{p}<.05)$. While the direct effect of the variable fear of negative evaluation on the variable of academic achivement and fear of negative evaluation variable on socio economic level variable have direct negative effect, the 
direct effects between all other variables are positive. The between group level the direct effect of the number of students per class and the number of students per teacher on the academic achievement variable is negative.

When the structural relations of the model were examined, the standardized path coefficient between socioeconomic and academic achievement variables was found as $\beta=0.133(p<.05)$. Accordingly, the direct impact of the socioeconomic level on the academic achievement of the students at the within group level is poor. An increase in socioeconomic level leads to an increase of 0.13 units in academic achievement.

The standardized path coefficient between fear of negative evaluation and academic achievement variable was found $\beta=-0.476(p<.05)$. Accordingly, the direct impact of the fear of having a negative assessment on students' academic achievements is moderate. A one-unit increase in fear of negative evaluation leads to a decrease of -0.47 in academic achievement. The standardized path coefficient between academic risk taking behavior and academic achievement variable was found $\beta=0.416(p<.05)$. According to this, the direct effect of academic risk-taking behavior on the students' academic achievement at the within group level is moderate. One-unit increase in academic risk-taking behavior leads to a 0.41 increase in academic achievement.

Socioeconomic status, fear of negative evaluation, risk-taking behavior and academic variables explain the variation in academic achievement along with $89.9 \%$ $\left(\mathrm{R}^{2}=.899\right)$. at the between group level the standardized path coefficient between the academic achievement and the class size was found $y=-0439(\mathrm{p}<.05)$ while it was found $y=0.348(p<.05)$ between the number of student per teacher and the academic achievement. At the ibetween group level, the direct effects of the number of students per class and the number of students per teacher on the academic achievement of the schools are moderate. The strongest effect among the variables discussed at school level is the class size. Class size and the number of students per teacher explain 39.9 $\%$ of the variability in the academic success of schools $\left(\mathrm{R}^{2}=.399\right)$.

The socioeconomic level explains \% 53.8 of the change in fear of negative evaluation $\left(\mathrm{R}^{2}=.538\right)$. The socioeconomic level has a direct, negative and strong impact on the fear of negative evaluation $[\beta=-0.734 ; p<.05]$. In other words, a oneunit increase in socioeconomic level leads to a decrease of 0.73 in the fear of negative evaluation. \% 68.9 of the variability in academic risk taking behavior is explained by the socioeconomic level variable $\left(\mathrm{R}^{2}=.689\right)$. Socioeconomic level has a direct, positive and strong impact on academic risk taking behavior $(\beta=0.830 ; p<.05)$.

There is a significant effect of the moderator variables of academic risk taking and the fear of negative evaluation on socioeconomic level variable predicting the academic achievement. The socioeconomic level variable has an indirect effect on the academic achievement points by academic risk-taking, as much as 0.349 , with academic risk taking variable to academic achievement points as much as 0.346 , 
through the fear of negative evaluation $(p<.05)$. The total impact of the socioeconomic level latent variable on academic success is 0.828 .

It is seen that the direct effects of the variables of the number of students per classroom and the number of students per teacher at the between group level are negative. The standardized path coefficient between the group size (school) and the academic achievement variable was $\beta=-0.439$ ( $\mathrm{p}<.05)$. Accordingly, the direct impact of the class size on the academic achievement of the students at the between group level is moderate. A one-unit increase in class size leads to a decrease of 0.44 in the success of schools.

\section{Discussion and Conclusions}

The effects of socioeconomic level, fear of negative evaluation and academic risk taking behavior on within group level were found to have a direct effect on academic achievement. While the effects of socioeconomic level and academic risk taking behavior on academic achievement are positive, the effect of the fear of negative assessment on the academic achievement is negative. The socioeconomic level variable affects academic achievement directly as well as the fear of negative evaluation and academic risk taking behavior. The impact of the socioeconomic level variable on the fear of negative evaulation is negative. As the socioeconomic levels of the students increase, the fear of negative evaluation decreases. The effect of socioeconomic level variable on academic risk taking behavior is positive. The direct effects of the number of students per class and the number of students per teacher on the between group level are significant. The effect of both variables on academic achievement is negative. As the number of students per class and the number of students per teacher increases, academic achievement points decrease.The socioeconomic levels of families have an important effect in student achievement especially at school level. According to the research, students in schools with high socioeconomic status have high success. It can be seen that the higher the education and income of parents, the higher the success of the students. Students with lower socioeconomic status do not have equal educational opportunities with their peers from socioeconomically advantageous families, which adversely affects learning. For this reason, it is recommended that state institutions dealing with education should produce policies to eliminate differences based on socioeconomic level and to ensure equal opportunities in education. As their parents' educational level increases, the academic support they will provide to their children will increase. Therefore, organizing educational environments in schools in such a way as to provide academic guidance to families and children with low levels of education can increase students' achievements. Investing in students from families with low socioeconomic status can be beneficial for social development.

It was found that fear of negative evaluation significantly predicted academic achievement. As students' fears of negative evaluation increase, their academic achievement decreases. One of the affective features that has an effect on students' learning and which should be considered is the fear of being evaluated negatively. 
Considering the effect of the fear of negative evaluation on students who are in adolescence, it is thought that teachers and their parents should avoid self-confidence and criticism of self-efficacy in front of their friends. Seminars can be given to the students and families in order to ensure that the school guidance units have realistic expectations about their children and that students get to know themselves better. In addition, school guidance units can carry out restructuring studies of non-functional ideas so that students can cope with negative emotions and thoughts in order to define students' fears of social anxiety and negative evaluation.

According to the results of the study, it is concluded that academic risk taking behavior has a positive effect on academic achievement. It can be said that strengthening the academic risk taking behavior which has a positive effect on student achievement and it will be beneficial for teachers to create problem situations or activities in which students can take risks. To give equal attention to each student in the classroom environment, to give positive feedback to students who take the right to speak can contribute to the development of risk taking behavior. 